\title{
Sosyal Siyaset Konferansları Dergisi ve Uluslararası Çalışma Örgütü (ILO)
}

\section{Journal of Social Policy Conferences and International Labor Organization (ILO)}

\author{
Verda Canbey Özgüler ${ }^{1}$ ()
}

Öz

Türkiye'de İstanbul Üniversitesi, İktisat Fakültesi Çalışma Ekonomisi ve Endüstri illişkileri Bölümü bünyesinde 1948 yılından beri yayın hayatına devam etmekte olan Sosyal Siyaset Konferansları Dergisi sosyal politika geleneğinin oluşmasında ve sürdürülmesinde önemli bir yere sahiptir. 1948 yılından günümüze kadar derginin geçirdiği aşamalar, değişim ve dönüşüm, Türkiye'de sosyal politika alanı ile ilgili olarak yapılmış olan çalışmalar için dikkate değer bir akademik ortam sunmaktadır. 1948 yılı, aynı zamanda Türkiye'nin onayladığı Uluslararası Çalışma Örgütü (ILO) sözleşmeleri bakımından önemli bir yıldır. 1932-1946 yılları arasında sadece bir ILO Sözleşmesini onaylayan Türkiye, 1946-1959 yılları arasında 11 sözleşme imzalamıştır. Bu bağlamda çalışma ilişkileri ve sosyal politika alanında uluslararası düzeyde önemli bir kurum olan ILO ile Türkiye’deki ilk sosyal politika külliyatını oluşturan derginin kuruluşu aynı yıllara rastlamaktadır.

Bu çalışmada 2019 yılında 100. yılına ulaşmış olan ILO ile 71. yılına ulaşmış Sosyal Siyaset Konferansları Dergisi nitel araştırma yöntemiyle analiz edilmektedir.

Sosyal Siyaset Konferansları Dergisinin analizi tek bir yönteme başvurulamayacak kadar derinliklidir. Zira derginin ortaya çıkışı ve tarihçesi incelendiğinde hakemli bilimsel dergi olma ölçütüne göre 2003 öncesi ve sonrası, basılı dergiden internet ortamına taşınması ölçütü ele alınırsa 2009 - 2010 öncesi ve sonrası gibi farklı dönemleştirmeler yapılabilecektir.

\section{Anahtar Kelimeler}

Sosyal Siyaset Konferansları Dergisi, Uluslararası Çalışma Örgütü (ILO), Doküman analizi, Bibliyometrik analiz

1 Sorumlu Yazar: Verda Canbey Özgüler (Prof. Dr.), Anadolu Üniversitesi, İktisadi ve İdari Bilimler Fakültesi Çalışma Ekonomisi ve Endüstri İlişkileri Bölümü, Eskişehir, Türkiye. E-posta: vcanbey@anadolu.edu.tr ORCID: 0000-0002-0662-4039

Atıf: Canbey Ozguler, V. (2019). Sosyal Siyaset Konferansları Dergisi ve uluslararası çalışma örgütü (ILO). Sosyal Siyeset Konferansları Dergisi, 77: 235-285. https://doi.org/10.26650/jspc.2019.77.0013 


\begin{abstract}
The Journal of Social Policy Conferences, which since 1948 has been published within the body of the Faculty of Economics, Labor Economics, and the Industrial Relations Department at Istanbul University, Turkey, has played an important part in the formation and maintenance of social policy tradition. With the stages, changes, and transformation that it has undergone from 1948 to the present, the journal offers an outstanding academic setting for research in the field of social policy in Turkey. In addition, 1948 is an important year in terms of the International Labour Organization (ILO) conventions approved by Turkey. Turkey, which ratified only one ILO convention between the years 1932 and 1946, signed 11 conventions between the years 1946 and 1959. In this context, ILO, which is an important institution at international level in the field of labor relations and social policy, and the journal that created the first social policy corpus in Turkey, were founded in the same period.

In this study, ILO, which reached its 100th year in 2019, and the Journal of Social Policy Conferences, which in the same year reached its 71st year, are analyzed using qualitative research method.

The Journal of Social Policy Conferences is too deep to be analyzed through a single method. This is because when the origin and history of the journal is examined, it is clear that different periodizations can be made (e.g before and after 2003 according to the criterion of being a peerreviewed scientific journal; before and after 2009-2010 based on the criterion of transfer to the internet environment from the printed journal).

Keywords

Journal of Social Policy Conferences, International Labor Organization (ILO), Document Review, Bibliometric Analysis
\end{abstract}




\section{Extended Summary}

The Journal of Social Policy Conferences, which since 1948 has been published within the body of the Faculty of Economics, Labor Economics, and the Industrial Relations Department at Istanbul University, Turkey, plays an important part in the formation and maintenance of social policy tradition. With the stages, changes, and transformation it has undergone from 1948 to the present, the journal offers an outstanding academic setting for research in the field of social policy in Turkey. In addition, 1948 is an important year in terms of the International Labour Organization (ILO) conventions approved by Turkey. Turkey, which ratified only one ILO convention between the years 1932 and 1946, signed 11 conventions between the years 1946 and 1959. In this context, ILO, which is an important institution at international level in the field of labor relations and social policy, and the journal that created the first social policy corpus in Turkey were founded in the same period.

The main hypothesis of this study is to highlight the importance within scientific and academic development of long-term academic publications being able to present to their readers the reflections of the social, political and economic developments of the periods with which they are concerned. Starting from this, the purpose of the study is to examine how ILO, which is one of the major international institutions in terms of industrial relations and working life, is reflected in the Journal of Social Policy Conferences as a journal that has been maintaining its publishing activities through 71 years.

This study firstly presents the history of the Journal of Social Policy Conferences. Then, within the scope of "Qualitative Analysis of the Journal of Social Policy Conferences", the articles in the journal are subjected to qualitative analysis regardless of periods. After that, the journal articles dealing with ILO, -and those covering the basic ILO conventions are examined under the title of "ILO in the Journal of Social Policy Conferences".

The literature review shows that different academic publications such as journals and graduate studies are analyzed through various qualitative research methods, namely document analysis, content analysis, and bibliometric analysis. With 71 years of history, the Journal of Social Policy Conferences is too deep to be analyzed through a single method. This is because when the origin and history of the journal is examined, it is clear that different periodizations can be made (e.g before and after 2003 according to the criterion of being a peer- 
reviewed scientific journal; before and after 2009-2010 based on the criterion of transfer to the internet environment from the printed journal).

In this article, the reflection of ILO in academia is presented through the Journal of Social Policy Conferences, the academic representative of the social policy field in the national arena. The fact that the study is the first one to subject the Journal of Social Policy Conferences to qualitative bibliometric analysis shows its originality. However, this originality also carries with it the difficulties of making an analysis that complies with the spirit of the journal. In this context, the study should be considered as an "exploratory" preliminary study that can guide future studies with how it all started and how it continued as well as the research method it employed.

The database used in the research was created by transferring all the files in the journal archive to the Excel program through the DergiPark system. Analyses were performed on 830 files excluding the records coded as "Imprint, Editorial, Table of Contents", "Editorial", and "Foreword" from among the those included in the dataset created within the scope of the study.

The calculation results indicate that the journal does not comply with the $80 / 20$ rule, which states that $80 \%$ of all articles published in the journal should be written by $20 \%$ of the authors, and neither does it comply with Price's law, which measures the productivity of the authors. However, it does comply with Lotka's law, which measures the contribution to the literature. In light of the calculation made according to Lotka's law, which is a quantitative estimation of how many articles the authors have contributed to the literature, it can be said that the 71-year journal will continue to contribute to the field as an academic platform in the following years as well.

There are 30 studies directly containing the word "ILO" in their titles. This number amounts to $3.6 \%$ of the total number of studies. There are few studies directly addressing ILO which can be repeated within the scope of the journal covered in the present study as well.

The Journal of Social Policy Conferences, which has grown and developed concurrently with the social policy history of Turkey, has aspects that, by maintaining its mission from tradition to future, flourish, create a tradition, sustain such tradition, and have a significant collective power. 


\section{Sosyal Siyaset Konferansları Dergisi ve Uluslararası Çalışma Örgütü (ILO)}

Bilginin yaygınlaşması, kolay erişilebilir hale gelmesi, bilgi çağının en önemli özelliklerinden biridir. Bilişim ve iletişim teknolojilerindeki gelişmeler yaşamın her alanında olduğu gibi akademik bilgi üretiminde ve yayılmasında da çok önemli değişimler ve dönüşümler ortaya çıkarmaktadır. Bilgisayar, internet ve çeşitli bilgisayar yazılımları sayesinde bilgilerin paylaşılması daha hızlı ve az maliyetli hale gelmektedir. Hatta eş zamanlı iletişim ve bilgi paylaşımı da söz konusu olmaktadır. Boratav, 2006'da ifade edildiği gibi hesaplamak için günlerce uğraşılan ekonomik katsayıların saniyeler içinde hesaplanabilmesi ya da daktilo ile çizilmesi uzun zaman alan tabloların kısa zamanda çizilebilmesi, değişiklik ve düzeltmelerin kolaylıkla yapılabilmesi günümüzde mümkün olmaktadır. Benzer şekilde fotokopinin olmadığ1 zamanlarda kitap ve makalelerden yararlanırken her araştırmacının kendine has geliştirdiği kâğıtlara ya da fişlere not alma gibi tekniklere artık ihtiyaç duyulmamaktadır (Boratav, 2006: 12).

Akademik bilgi üretme sürecinde önemli bir yeri olan yayıncılık ve özellikle de periyodik yayıncılık akademik araştırma yapabilmek için çağdaş ve uzmanlaşmış kitaplıkların oluşumunda yaşamsal öneme sahiptir. Ancak günümüzde yaşanan bilişim iletişim teknolojileri gelişmeleri bilginin yayınlanması ve paylaşılması konusunda kullanıcılara önemli fırsatlar sunmaktadır (Timur, 2006:21). Ancak internet erişimi engelleri, veri tabanlarının açık erişim yerine ücretli olanları gibi kullanıcılar bakımından sınırlayıc1 durumlar da söz konusudur. Bilginin özgürce ve sınırsız paylaşılabilmesi önemlidir. Akademik bilgi paylaşımının genel internet kullanımı içinde önemli bir rolü bulunmaktadır. Zira internet ortamında kontrolsüz ve bilimsel temele dayanmayan, akademik süreçlerden geçmemiş ve kullanıcıları yanlış yönlendiren bilgiler de bulunmaktadır. Bu bağlamda akademik bilgi üretimi süreçlerinden geçmiş nitelikli yayınların okuyuculara maliyetsiz ve kolaylıkla ulaştırılması büyük önem arz etmektedir. Türkiye'de akademik alanda bunun bilincinde olarak yayın faaliyetini sürdüren az sayıda yayın bulunmaktadır (Timur, 2006: 20).

1948 yılından günümüze kadar yayın hayatını sürdüren Sosyal Siyaset Konferansları Dergisi akademik bilgiyi üretme ve yayma anlamında önemli bir rol üstlenmektedir. Akademik bilginin üretilmesi sürecinde kuruluşundan 
başlayarak akademideki bilgi birikimini uygulama boyutuna ve topluma yaymayı hedefleyen dergi basılı olduğu zamanlarda olduğu kadar (ve belki daha fazla oranda) internet ortamına taşındığında da bilgiyi yayma fonksiyonunu kuvvetlendirmiştir.

Günümüzde elektronik ortamda yayın yapan çok sayıda dergi bulunmakta, üniversiteler kütüphanelerinde bulunan basılı malzemeleri elektronik ortama taşımak konusunda önemli çalışmalar yapmaktadırlar. Bu yolla oluşan "Açık Arşiv" uygulamaları ve veri tabanları araştırmacıların bilgiye daha hızlı, kolay ve maliyetsiz olarak ulaşabilmelerini mümkün kılmaktadır. Yürütülen bu araştırmada da kullanılan kaynakların neredeyse tamamı elektronik ortamlardan elde edilmiştir. Bu nedenle yürütülen araştırma özü itibarıyla keşfedici çalışmalar kategorisinde değerlendirilebilir. Türkiye'de sosyal politika disiplini açısından olduğu kadar üniversitelerin topluma karşı sorumluluklarını yerine getirme, nitelikli akademik bilgiyi üretme ve yayma fonksiyonunu 71 yıldır sürdüren Sosyal Siyaset Konferansları Dergisi'nde yer alan makalelerin nitel analiz yöntemleriyle incelendiği bu çalışmada;

- Sosyal Siyaset Konferansları Dergisi'nde yıllar bazında makale dağılımı nasildir?

- Sosyal Siyaset Konferansları Dergisi’nde yazar profili nasıldır?

- Sosyal Siyaset Konferansları Dergisi'nde yayımlanmış makalelerin yayın diline göre dağılımı nasıldır?

- Sosyal Siyaset Konferansları Dergisi'nde yer alan makalelerin internetten görüntülenme ve elde edilme sayıları nedir?

sorularının yanıtları verildikten sonra ILO ile ilgili çalışmalar dönemler halinde sunulmaktadır. Sosyal politika alanının ulusal alandaki akademik temsilcisi Sosyal Siyaset Konferansları Dergisi ile ILO'nun akademideki yansıması sunulmaktadır. Sosyal Siyaset Konferansları Dergisi'nin bibliyometrik analiz ${ }^{1}$ yöntemiyle nitel olarak ilk kez analiz edilmesi bu çalışmanın özgünlügünü ortaya koymaktadır. Ancak bu özgünlük derginin ruhuna yakışır bir analiz yapabilmenin zorluklarını da taşımaktadır. $\mathrm{Bu}$ bağlamda çalışma, araştırma yönteminde olduğu gibi ortaya çıkışı ve ele

1 Belirli bir alanda belirli bir dönemde ve belirli bir bölgede kişiler ya da kurumlar tarafından üretilmiş yayınların ve bu yayınlar arasındaki ilişkilerin sayısal olarak analizidir. https://cabim.ulakbim.gov.tr/ bibliyometrik-analiz/bibliyometrik-analiz-sikca-sorulan-sorular/, (07.10.2019). 
alınışında da izleyen çalışmalar için fikir verebilecek "keşfedici" bir ön çalışma olarak değerlendirilmelidir. Bu çalışmanın temel hipotezi genel olarak uzun dönemli akademik yayınların ilgili olduğu dönemin sosyal, siyasal ve ekonomik gelişmelerinin yansımasını okuyuculara sunabilmesinin bilimsel ve akademik gelişme için önemli olduğudur. Bu düşünceden hareketle Türkiye'de 71 yıllık bir dönemde yayın faaliyetini sürdürmüş bir dergi olarak Sosyal Siyaset Konferansları Dergisi'nde endüstri ilişkileri ve çalıma hayatı bakımından temel uluslararası kurumlardan biri olan ILO'nun akademik çalışmalara nasıl yansıdığının incelenmesidir.

\section{Sosyal Siyaset Konferansları ve Sosyal Siyaset Konferansları Dergisi}

İstanbul Üniversitesi bünyesinde 1948 yılında başlayan "İçtimai Siyaset Konferansları" 1961 yılından itibaren "Sosyal Siyaset Konferansları" adını almıştır. Ağırlıklı olarak işçilere ve sendikalara yönelik olarak yürütülen konferanslar İstanbul dışında da farklı illerde de yürütülmüş olan konferanslar daha sonra basılı hale getirilmiştir. Sosyal Siyaset Konferansları Dergisi'nin temelini de bu konferanslar oluşturmaktadır.

Konferansların basılı hale getirildiği kitaplara basılı olarak ulaşılabildiği gibi derginin TÜBİTAK ULAKBİM DergiPark bünyesinde bulunan arşivinden de ayrı dosyalar halinde elde edilebilmekte ve incelenebilmektedir. Örneğin, Sosyal Siyaset Konferansları'nın 20. yılı münasebetiyle yazılmış yazıda birçok süreli yayının uzun süreli olmadığını vurgulayan Tuna, 1969'da İktisat ve İçtimaiyat Enstitüsü² mensuplarının emek ve çabalarıyla 1969 yılı itibarıyla 20 ciltlik bir eser kazandırıldığını ifade etmektedir (Tuna, 1969: 1). İşçi ve işveren ilişkilerinin başlangıç aşamasında olduğu, emek piyasasının doğuş halinde olduğu bir dönemde 20 ciltlik külliyat sosyal sorunlarla ilgilenenler için ilk sırada başvurulacak bilimsel bir kaynak olma niteliği kazanmıştır.

1947 y1lında ilk Sendikalar Kanunu'nun kabulünden sonra Türkiye'de dernek hayatı birden canlanmış işçi dernek ve sendikalarının doğmasına paralel olarak sendikal yayınlarda da artış olmuştur. Bu dönemde üniversitelerle de temas

21933 yılında çıkan kanunla 1934 yılında İstanbul Üniversitesi kurulduğu zaman henüz sadece Hukuk Fakültesi bulunmaktaydı. İçtimai Bilimler sahada Hukuk ve Edebiyat Fakültesi, Tıp ve Fen vardır. Hukuk Fakültesi'ne bağlı olarak iktisadi ve içtimai sahada araştırma yapmak üzere İktisat ve İçtimaiyat Enstitüsü kurulmuştur. 1936 yılında İktisat Fakültesi kurulunca bu enstitü fakülteye bağlanmıştır. İktisat kısmı iktisat kürsüleri olarak ayrılmış geriye kalan içtimaiyat ise bizim bölümün adı oldu. Sonra bu enstitü içinde İçtimaiyat (Sosyoloji) ve İçtimai Siyaset (Sosyal Siyaset) oluştu (Zaim, 2007: 328). 
kurulmuştur. Sosyal sorunlarla ilgilenen hocalar, sendikacilık hareketleri ve uygulamaları ile ilgili teorik ve uygulamalı bilgilerin, hafta sonları sendika merkezlerinde veya işyerlerinde paylaşıldığ 1 sohbet toplantılarını yürütürken 1947-1948 ders yılı başında İstanbul Üniversitesi İktisat Fakültesi Dekanlığı'na altı fakülte hocasının verdiği dilekçe ile Sosyal Siyaset Konferansları'nın nüvesini oluşturacak yapı oluşturulmuştur. Kutal, 2011'de de;

“.......Kessler'in bu konferanslart başlatması bir tesadüfün eseri değildir. Çünkü Türkiye 1945 yılında, 1946 yllında çok partili düzene geçebilmek için ciddi adımlar atmaya başlamıştır. Elbette ki çok partili düzen çoğulcu bir demokrasinin işaretleridir. Çoğulcu demokrasinin vazgeçilmez öğelerinden ikisi, biri siyasal partiler ise ötekisi özgür sendikalardır. Dolayısiyla Prof. Kessler 1946 yllında bu konferanslara başlarken yakında bir sendikalar kanunu çıkacak ki 1947 Sendikalar Kanunu'ndan söz ediyorum. Ancak bu kanunun çıkmasl yetmez, mutlaka bu kanunun aktörlerini eğitmek gerekir. Bu bize düşen bir görevdir demiş ve Sosyal Siyaset Konferansları'nı kurmuştur'"

ifadelerine yer verilmektedir (Kutal, 2012: 110).

Sosyal Siyaset Konferansları serisinin temel yapısı bazen genel ve teorik sosyal siyaset konularına, bazen de devleti ve halkı ilgilendiren günlük sorunlara yönelik oluşmuştur. İstanbul Üniversitesi İktisat ve İçtimaiyat Enstitüsü'nün altı tane özlü ve kuvvetli konferanstan oluşan 125 sayfalık birinci cildin basımı sonrasında 16.01.1949 tarihli Hürriyet Gazetesi'nde yazan İbrahim Alâaddin Bey tarafından;

“....memleketimizdeki işçi hareketlerini, sendikalart, muhtelif şekildeki kooperatifleri, gerek ziraat, gerek sanayi sahasindaki işçilerimizin bugünkü şartlarıla bu şartların daha iyiye doğru tekemmül etmesi için göz önünde bulundurulmass faydalı olan meseleleri, nihayet sosyalizm, komünizm, gibi bahislerin bugünkü hakiki mahiyetlerini pek açık bir şekilde hülâsa edilmiş buldum. Bundan dolayıdır ki öteki konferansların ve onlart ihtiva edecek kitapların da bunu takip etmesini ehemmiyetle temenniye lâyik buldum"

düşünceleri paylaşı1mıştır (Tuna, 1969: 3). 
Sosyal Siyaset Konferansları'na biraz şüphe ile bakılan yıllar olduğunu Kutal (2011: 484)

“Özellikle 1950’li yullarda rahmetli hocamız Prof. Dr. Orhan Tuna hakkında, "bu adam daha ilkokul mezunu dahi olmayan birtakım sendika başkanlarını üniversite kürsülerine çıkartıyor ve onlara bir takım kötü ideolojiler aşıllyor" gibi iddialarla karşı karşılya gelmiştir. T.B.M.M.'de, o zamanki Çalışma Bakanının teşvikiyle, Orhan Tuna ile ilgili görüşmeler yapılmıştır. Yani öyle bir gelenekten geliyor ki sosyal siyaset konferansları, zaman zaman çok büyük güçlükleri de göğ̈̈slemek mecburiyetinde kalmışlardır. Tabi böyle bir hareketin bugün 60. yılı olduğunu söylediler arkadaşlarımı veya 62. yılı; bunun bu sene için başlatılması hepimizi heyecanlandırıyor." şeklinde ifade etmektedir.

Sosyal Siyaset Konferansları'nın başladığı dönemlerden itibaren ne denli önemli bir rol üstlendiğini anlayabilmek için Prof. Dr. Sedat Murat ile Prof. Dr. Nevzat Yalçıntaş'ın açılış konuşmasındaki diyalogunu aktarmak yerinde olacaktır (Gökçen ve Murat, 2011: 479);

"Gerhard Kessler, Orhan Tuna, Sabahattin Zaim hocamiz sosyal siyasetin hem kurumsal anlamda hem de yasal mevzuatlar açısından, bunların oluşması bakımından, Türk çalışma hayatına çok önemli katkılar sağlamışlardır. Ĕger bugün, Türk çalışma hayatı bugünkü hale gelmişse, bunda çok önemli katkıları vardır. Türk çalışma hayatına yön vermişlerdir. Fakat her şey, bugünkü rahat ortamda olduğu gibi değildi, ulaşım imkânlarının, maddi imkânların oldukça sıkıntılı olduğu bir dönemde gerçekten bu işe gönül vermişlerdir. Her birinin belki yüzlerce, binlerce katklarl vardır. Hocalarımızdan duyardik: Nevzat Yalçıntaş hocamız, zannediyorum Zonguldak mıydı hocam? Bir bölgeye işçi seminerlerine gidiyorlar. Soruyorlar işçilere, "sendikalı misin? Hocam ne diyorlardl?

Prof. Dr. Yalçıntaş: Urfalıyım.

Prof. Dr. Murat: Urfalıyım. Sendikalı değilim, Urfalıyım veyahut da "Ağrılıyım, Karslıyım." Tabi sendikanın henüz ne olduğu daha bilinmiyor. Yani işçiler tarafindan "sendikalı misın?" sorusuna 
cevap "hayır Urfallyım." Ama "Trabzonluyum” demezler değil mi hocam? Bölümümüzün gerçekten Türk çalışma hayatına katklsı olduğunu tekrar söylemek isterim."

Sosyal Siyaset Konferansları'nın dergi olarak yayınlanması süreci uzun bir zamana yayılmış, kararlı ve kolektif bir çabanın ürünüdür. Sosyal Siyaset Konferansları Dergisi, emek-sermaye ilişkileri, işsizlik, yoksulluk, sosyal yardımlar, sosyal hizmetler ve dezavantajlı gruplara yönelik politikalar gibi sosyal politikanın konularını kapsayan bir dergidir. İlk olarak 1948 yılında "İçtimai Siyaset Konferansları" adıyla basılmaya başlanmıştır. Prof. Kessler tarafından hazırlanan Sosyal Siyaset Konferansları, Türkiye'deki ilk sosyal politika külliyatını oluşturmakta (Altan, 2007: 37) ve İstanbul Üniversitesi İktisat Fakültesi yayınları arasında önemli bir yer tutmaktadır. Sosyal Siyaset Konferansları başlangıcında daha çok işçi ve işverenleri aydınlatma ve bilgilendirme amacı taşımakta iken 1960'l1 yıllardan sonra pratik amaçlara yönelik konferansların yanı sıra sosyal politika, iş hukuku ve çalışma ilişkileri konularında bilimsel yazı ve çeviriler yayınlanmaya başlanmıştır (Dereli, 2003: i). Dergi bu özelliğini korumakla birlikte 2003 yılından itibaren de hakemli ve bilimsel bir dergi olarak yayın hayatına devam etmektedir. Dergi ortaya çıkışına konu olan ve 2011 yılı Sayı 70'e kadar dergi sayılarında yer alan "konferanslar"3 için belli konulara yoğunlaşmaktadır. Derginin web sayfandan elde edilebilen "ilk editör yazısı" H. İbrahim Sarığlu'na aittir ve bu yazıda editör dergiye gelen ve hakem sürecini tamamlayan makale sayısının azlığı nedeniyle sosyal siyaset disiplini dışında, genel iktisat bilimi ile ilgili yazıların da yayınlanacağını duyurmaktadır (Sarığlu, 2003: ii-iv). Derginin "hakemli" ve "bilimsel" dergi statüsünün genç öğretim elemanlarını teşvik edeceğini ifade eden Dereli, 2003'ün bu tespiti dergiyi sürdürülebilir kılmak için verilen emeklere de atıf yapmaktadır (Dereli, 2003: i).

3 Örneğin 45. Sayı editör notunda derginin konferanslar bölümünde son iki yılın konferanslarından bazılarının yayınlandığı ifade edilmektedir. “...önümüzdeki sayıda da çıkacak diğer yazılarla serileri tamamlamış olacağız. Konferansçılardan hocamız Prof. Dr. Nusret Ekin'i, derginin yayım aşamasında kaybetmenin üzüntüsü içindeyiz ve kendisini tatl üslubu ile daima hatırlayacağız. 2003 Yllı Konferansları'nı Iss Kanunu'nun yenilenmesini beklediğimizden gecikmeli olarak yapacă̆ız ve yayınlayacağız" ifadesi yer almaktadır. Benzer şekilde 47. Sayıda da Geleneksel Sosyal Siyaset Konferansları dizisinin Cumhuriyetin 80. 55. Serisinin 2003 yllı sonbaharında gerçekleştirildiği ifade edilmektedir (Sarıŏlu, 2004: i-iii). 
Araştırma kapsamında kullanılan dergi sayıları ve yayım yılları ile makale dosyaları DergiPark web sayfasından elde edilmiştir. ${ }^{4}$ Dergi hem basılı olarak hem de internet aracılığıyla okuyucularıyla buluşmaktadır. Birinci sayısından başlayarak "pdf” dosyaları biçiminde İstanbul Üniversitesi E-Dergi Sistemine ${ }^{5}$ aktarılmış olan dergi (Özdemir, 2011a: iii-v), 58. sayısından itibaren ASOS Index $^{6}$ tarafindan taranmaktadır. Sosyal Siyaset Konferansları Dergisi 60. sayısından itibaren de dünyanın sayılı endekslerinden biri olan EBSCO tarafından taranmaya başlayarak uluslararası bir nitelik kazanmıştır (Özdemir, 2011b: iii-v). Dergi günümüzde, akademik yayıncılık bakımından temel misyonlarından biri Türkiye'nin bilimsel bilgi birikimini yansıtacak ürünler geliştirmek olan ULAKBIMM tarafından uluslararası standartlara uygun olarak geliştirilen TR Dizin (2013 yılı sonuna kadar Ulusal Veri Tabanları-UVT adıyla yürütülen) kapsamında da yer almaktadır.

\section{Sosyal Siyaset Konferansları Dergisi'nin Nitel Analizi}

$\mathrm{Bu}$ başlık altında araştırmada kullanılan yöntem ve bulgulara yer verilmektedir.

\section{Yöntem}

Bu çalışmada verilerin analizinde betimsel analiz yöntemi kullanılmıştır. Makaleler yayınlanan dergi, yıl, dil, yazar sayısı, internetten görüntülenme ve indirilme gibi değişkenler ele alınarak incelenmiştir. Araştırmaya konu olan dokümanlar DergiPark platformundan Sosyal Siyaset Konferansları Dergisi'nin tüm sayılarının yer aldığı arşivden 07.08.2019 ve 23.08.2019 tarihleri arasında elde edilerek bir excel veri tabanı oluşturulmuştur.

42013 yılında başlayan Dergipark Projesi Ulusal Atıf Dizini için temel oluşturması planlanan ve 2019 yılı itibarıyla toplam akademik dergi sayısının 2.300 civarında olduğu bir platformdur. Türkiye'de yayınlanan tüm dergileri kapsayacak şekilde genişletilmesi hedeflenen Dergipark önemli bir akademik bilgi birikimi sunmaktadir. https://dergipark.org.tr/, (21.08.2019).

5 İstanbul Üniversitesi E-Dergi sistemi 2009-2010 yıllarında kurulmuş ve dergi arşivi sisteme yüklenmiştir. 2013 yılında DergiPark sisteminin oluşturulmasıyla dergi bu platforma taşınmıştır. Bilgi için derginin Yönetici Editörlerinden Arş. Gör. Sera Yıldırım’a teşekkür ederim.

6 Akademia Sosyal Bilimler Endeksi (ASOS Index), Çalışma Ekonomisi ve Endüstri İlişkileri camiasından aynı zamanda İş Güç: Endüstri İlişkileri ve İnsan Kaynakları Dergisi editörlüğü görevini de yürüten Aşkın Keser'in uzun yıllar boyunca verdiği emeğin/gayretin bir sonucu olarak ortaya çıkmıştır. 
Tablo 1

Dergi Kapsamındaki 854 Dosyanın Türlere Göre Dă̆ılımı

\begin{tabular}{ll}
\hline Yayın Türleri & \\
\hline Makaleler & 734 \\
Hatıra yazıları & 41 \\
Konferanslar & 36 \\
Diğer yayınlar & 22 \\
Künye, Editörden, İçindekiler & 13 \\
Editör yazısı & 5 \\
Kitap incelemesi & 1 \\
Olay incelemesi & 1 \\
Önsöz & 1 \\
Genel Toplam & 854 \\
\hline
\end{tabular}

Araştırma kapsamında oluşturulan veri tabanında "Künye, Editörden, İçindekiler", "Editör yazısı" ve “Önsöz” olarak kodlanmış bulunan kayıtlar hariç tutularak analizler 830 dosya üzerinden yapılmıştır. Bu dosyalardan 10 tanesine "tam metin" erişimi sağlanamamaktadır. Ancak analize konu olan bilgilere ulaşılabildiği için bu kayıtlar analiz kapsamından çıkartılmamıştır.

Araştırma kapsamındaki çalışmalar; yıllara ve dergi sayılarına göre dağılımı, yazar profili, yayın dili, internetten görüntülenme ve elde edilme sayıları ile ilgili bilgiler kapsamında incelenmiştir. ${ }^{7}$ Bibliyometrik analiz kapsamında yapılan bu analizler dergilerin ilgili disiplindeki niteliklerini öne çıkaran verilerin elde edilerek değerlerinin ölçülmesinde kullanılmaktadır. Dergilerin bibliyometrik analizinde; ilgili olduğu alana en çok katkı veren ülkeler, üniversiteler, yazarlar ve araştırma kategorileri tespit edilmektedir (Çetinkaya-Bozkurt ve Çetin, 2016: 231).

Günümüzde doküman analizi, içerik analizi gibi nitel araştırma yöntemlerinin yanı sıra birçok disiplinde uygulama alanı bulan bibliyometri, belli bir alandaki yayın örüntülerini tanımlamak için dergilerin, bildirilerin ve lisansüstü yayınların analizinde kullanılan niceliksel ve istatistiksel bir analiz tekniğidir (Tonta, 2009). Bibliyometrik analiz ile elde edilen bulgular, bilim dallarındaki ilerlemeler ve geçirilen evreler hakkında bilgi verdiği gibi geleceğe yönelik değerlendirmeler yapılmasına da imkân sağlamaktadır (Çatı ve Öcel, 2018: 509).

7 Yazar unvanları, çalıştıkları kurumlar anahtar kelimeler, her makale için elde edilememektedir. 
Bibliyometrik araştırmaların en önemli veri kaynakları, Science Citation Index (SCI), Social Sicence Citation Index (SSCI) ve Art\&Humanities Citation Index (A\&HCI) olmak üzere uluslararası bilimsel atıf indeksleridir (Güzeller ve Çeliker, 2017: 89). Türkiye' de de Ulusal Atıf Dizini oluşturulması amaçlanarak uygulamaya konulmuş olan DergiPark da önemli bir veri kaynağıdır.

Bu çalışmada toplam çalışmaların \%80'inin yazarların \%20'si tarafından yazılmış olması gerektiğini belirten 80/20 kuralı, yazarların verimliliğini ölçen Price Yasası ve yazarların literatüre katkısını kaç çalışma ile bu katkıyı sağladıklarını gösteren Lotka Yasası kullanılmıştır. Bradford ve Lotka yasaları betimsel bibliyometrik olarak da adlandırılmaktadır (Doğan, 2018). Ancak bu sonuçlarla ilgili değerlendirme yapılırken derginin kendine has yapısı gözden kaçırılmamalıdır.

\section{Bulgular}

$\mathrm{Bu}$ başlık altında makalelerin yıllara ve dergi sayılarına göre dağılımı, yazar profili, yayın dili, internetten görüntülenme ve elde edilme sayıları ile ilgili açıklamalara yer verilmektedir.

Tablo 2

Sosyal Siyaset Konferansları Dergisi’nde Yer Alan Çalışmaların Yıllara ve Dergi Sayılarına Göre Dağılımı

\begin{tabular}{lcccccccc}
\hline Yıl & $\begin{array}{c}\text { Dergi } \\
\text { Sayısı }\end{array}$ & $\begin{array}{c}\text { Makale } \\
\text { Sayısı }\end{array}$ & Yıl & $\begin{array}{c}\text { Dergi } \\
\text { Sayıs }\end{array}$ & $\begin{array}{c}\text { Makale } \\
\text { Sayıs }\end{array}$ & Yıl & $\begin{array}{c}\text { Dergi } \\
\text { Sayısı }\end{array}$ & $\begin{array}{c}\text { Makale } \\
\text { SayıSı }\end{array}$ \\
\hline 1948 & 1 & 5 & 1975 & 26 & 6 & 2007 & 52 & 13 \\
1949 & 2 & 7 & 1976 & 27 & 6 & 2007 & 53 & 37 \\
1950 & 3 & 7 & 1977 & 28 & 6 & 2008 & 54 & 10 \\
1951 & 4 & 6 & 1978 & 29 & 7 & 2008 & 55 & 5 \\
1952 & 5 & 5 & 1979 & 30 & 10 & 2009 & 56 & 17 \\
1954 & 6 & 8 & 1982 & 31 & 27 & 2009 & 57 & 18 \\
1955 & 7 & 10 & 1983 & 32 & 7 & 2010 & 58 & 11 \\
1956 & 8 & 8 & 1984 & 33 & 9 & 2010 & 59 & 9 \\
1960 & 910 & 16 & 1985 & 34 & 8 & 2011 & 60 & 16 \\
1961 & 12 & 8 & 1986 & $35-36$ & 14 & 2011 & 61 & 11 \\
1962 & 13 & 13 & 1992 & $37-38$ & 15 & 2012 & $62-63$ & 6 \\
1963 & 14 & 7 & 1993 & 39 & 10 & 2013 & $64-65$ & 5 \\
1964 & 15 & 19 & 1995 & 40 & 17 & 2014 & $66-67$ & 7 \\
1965 & 16 & 15 & 1998 & $41-42$ & 19 & 2015 & 68 & 8 \\
1966 & 17 & 14 & 2000 & $43-44$ & 24 & 2015 & 69 & 6 \\
1967 & 18 & 16 & 2003 & 46 & 9 & 2016 & 70 & 5 \\
1968 & 19 & 19 & 2003 & 45 & 10 & 2016 & 71 & 5 \\
1969 & 20 & 15 & 2004 & 47 & 16 & 2017 & 72 & 8 \\
1970 & 21 & 15 & 2004 & 48 & 13 & 2017 & 73 & 9 \\
1971 & $22-23$ & 13 & 2005 & 49 & 52 & 2018 & 74 & 6 \\
1972 & 24 & 13 & 2005 & 50 & 54 & 2018 & 75 & 11 \\
1974 & 25 & 7 & 2006 & 51 & 14 & 2019 & 76 & 8 \\
\hline
\end{tabular}

Tabloda yer alan işaretli kısımlar derginin özel sayılarını göstermektedir. Ayrıntılı bilgi Tablo 3’te verilmektedir. 
1948 yılından itibaren dergi sayıları ve içerdiği makaleleri gösteren Tablo 2 incelendiğinde derginin konferanslar, armağanlar gibi sayıları da olduğu için her sayı aynı sayıda makale ile çıkmamıştır. Ortalama makale sayısı 12'dir ve 2005 yılındaki 50. Sayı en fazla makalenin yayınlandığı sayıdır (54 makale), yine 2005 yılındaki 49. Sayı 'da 52 makale yayınlanmıştır.

Tablo 3

Sosyal Siyaset Konferansları Dergisi’nin Armağan Olarak Yayımlanan Sayıları

\begin{tabular}{lll}
\hline Yıl & Sayı & Armağan \\
\hline 1982 & 31 & Prof. Dr. Orhan Tuna'ya Armağan \\
& 49 & Prof. Dr. Turan Yazgan'a Armağan \\
2005 & 50 & Prof. Dr. Nevzat Yalçıntaş'a Armağan \\
2007 & 53 & Prof. Dr. Haşmet Başar'a Armağan \\
& 68 & Prof. Dr. Gülten Kutal'a Armağan \\
2015 & 69 & Prof. Dr. Gülten Kutal'a Armağan \\
& 70 & Prof. Dr. Bengü Dereli'ye Armağan \\
2016 & 71 & Prof. Dr. Bengü Dereli'ye Armağan \\
& 72 & Prof. Dr. Ömer Alparslan Aksu'ya Armağan \\
2017 & 73 & Prof. Dr. Ömer Alparslan Aksu'ya Armağan \\
\hline
\end{tabular}

Dergi sayılarının \% 10'un hocalara armağan olarak çıkartılmıştır. Akademide armağan geleneği yaşatılması gereken bir durumdur. Derginin bu anlamda da öncü bir rol üstlendiği söylenebilir. 1943 yılından günümüze kadar yayın faaliyetlerine devam eden Ankara Üniversitesi Siyasal Bilgiler Fakültesi Dergisi $^{8}, 2004$ yılından beri yayın faaliyetlerine devam eden Çalışma ve Toplum Dergisi ${ }^{9}$ gibi dergiler de armağan sayılar yayımlamaktadır.

Tablo 4

Sosyal Siyaset Konferansları Dergisi'nde Yer Alan Çalışmaların Yazarları

\begin{tabular}{lcc}
\hline Yazar & Sayı & $\begin{array}{c}\text { Yüzde } \\
\mathbf{( \% )}\end{array}$ \\
\hline Orhan Tuna & 27 & 3,25 \\
Metin Kutal & 20 & 2,29 \\
Sabahaddin Zaim & 18 & 2,17 \\
Toker Dereli & 17 & 2,17 \\
Nusret Ekin & 17 & 2,05 \\
Ekmel Zadil & 14 & 1,69 \\
Tekin Akgeyik & 14 & 1,69 \\
Suphi Okay & 11 & 1,33 \\
10 Makale ve Daha Fazla Yazan Yazarlar Toplamı & 138 & 16,64 \\
10 Makaleden Daha Az Yazan Yazarlar Toplamı & 692 & 83,36 \\
Genel Toplam & 830 & 10,00 \\
\hline
\end{tabular}

8 https://dergipark.org.tr/tr/pub/ausbf/archive, (05.09.2019).

9 http://www.calismatoplum.org/, (05.09.2019). 
Tablo 4'te Sosyal Siyaset Konferansları Dergisi'nde 10 ve daha fazla sayıda çalışması bulunan yazarlar verilmektedir. Her yayında olduğu gibi akademik yayınlarda da yazılan makaleler ve bu makalelerin yazarları ortaya çıkan kolektif ürün olarak dergiye ve uzun dönemli olarak da ilgili oldukları akademik alana katkıda bulunurlar. Sosyal Siyaset Konferansları Dergisi'nde Orhan Tuna, Metin Kutal, Sabahaddin Zaim, Toker Dereli, Nusret Ekin, Ekmel Zadil, Suphi Okay ve Tekin Akgeyik tarafından yapılan 138 çalışma toplam çalışmaların \%16,64'ünü oluşturmaktadır. Tablo verilerinin sunumu 80/20, Price ve Lotka Yasası (Egghe, 1986'dan aktaran Yılmazel, 2019: 10) sonuçları değil, genel sıklık ve yüzdelerdir.

Derginin kendine özgü yapısı nedeniyle ilk sayılarının genellikle konferans sayıları şeklinde yayınlanması, armağan sayılarında hakemsiz çalışmalara yer verilmesi gibi unsurlar nedeniyle Tablo 2'de yer alan makale sayılarına göre 80/20 Kuralı, Price Yasası ve Lotka Yasası hesaplamalarının sonuçları dikkatli yorumlanmalıdır. 80/20 Kuralı bakımından yapılan hesaplamada 830 çalışmanın \%80’inin (664 çalışma) yazarların \%31'i (602 yazar içinde 191 yazar) tarafından yazılmış, 2003 yılı sonrasında ise çalışmaların \%80'i (2003 sonrası için 399 çalışma) yazarların \%19,94'ü tarafından yazılmış olduğu bulunmuştur. Derginin 2003 yılı öncesi için 80/20 Kuralına uygun değilken bu tarihten sonrası için uyumlu olduğu görülmektedir.

Yazarların verimliliğinin ölçümü olan toplam yazar sayısının karekökü kadar yazarın toplam makale sayısının yarısını yazması gerektiğini öngören Price Yasası gereği 25 yazarın 415 makale yazması gerekmektedir. En verimli 8 yazarın toplam 138 makale yazdığı görülmektedir. Price Yasası hesaplaması 2003 sonrası için yapıldığında en verimli 18 yazarın 2003 sonrasında yer alan 399 çalışmanın 200'ünü yazmış olmaları gerekirken, 112'sini yazmış oldukları görülmektedir. Dergi tüm yıllar ve 2003 sonrası için Price Yasasına uyumlu değildir.

Literatüre katkısı olan yazarların bu katkıyı kaç yazı ile sağladıklarının niceliksel olarak tahmini olan Lotka Yasası'na göre yayın yapan yazarların \%60'1 bir makale ile \%15'inin iki makale ile \%7'sinin de üç makale ile katkıda bulunması beklenmektedir. Tüm yıllar bazında Sosyal Siyaset Konferansları Dergisi için yazarların \%51,36's1 1 makale ile \%12,96's1 2 makale ile \% 6,12'si de 3 makale ile katkıda bulunmuştur. 2003 yılı sonrası için ise yazarların \%63'ü 1 makale, \% 12'si 2 ve \%3’ü de 3 makale ile katkıda 
bulunmuşlardır. Elde edilen bu veriler 1şığında Dergi'nin 2003 yılı öncesinde Lotka Yasası'na yakın bir uygunlukta olduğu söylenebilir. Yazarların ileride yapmaları beklenen katkıyı gösteren bir hesaplama olduğu göz önünde bulundurulduğunda 2003 yılı öncesi yayın ve yazar sayılarına yakın değerlere ulaştığında alana katkısının daha da artacağı söylenebilir. Bu bağlamda ULAKBİM veri tabanında taranmaya başlaması ile daha fazla çalışma dergiye yönlenebilir. Elbette bu durumun yayın politikası ile de ilgisi vardır. Her sayıyı belli sayıda makale ile çıkarma kuralı olup olmaması, hakem değerlendirmesi sürecinden geçebilen makaleler gibi ölçütler de burada etkilidir.

Tablo 5

Sosyal Siyaset Konferansları Dergisi’nde Yer Alan Çalışmaların Yayın Diline Göre Dağılımı

\begin{tabular}{lcc}
\hline Yayın Dili & Sayı & Yüzde (\%) \\
\hline Türkçe & 788 & 94,94 \\
İngilizce & 39 & 4,70 \\
Almanca & 3 & 0,36 \\
Genel Toplam & 830 & 100,00 \\
\hline
\end{tabular}

Dergi'de yayınlanmış olan çalışmaların neredeyse tamamı Türkçe'dir. Bu bakımdan Dergi'nin Türkçe literatüre katkıda bulunduğu söylenebilir. Bu durum Türkiye'de sosyal politika külliyatı olma özelliğine sahip bir dergi olarak oldukça önemlidir. Ancak Dergi'nin İngilizce yayının son derece düşük olması ise, Türkiye'nin sosyal politika birikiminin uluslararası akademik camiada çok az bilinebilme imkânı anlamına geldiği de not edilmelidir.

Tablo 6

Sosyal Siyaset Konferansları Dergisi'nde Yer Alan Çalışmaların Internetten Görüntülenme ve Elde Edilme Sayllart

\begin{tabular}{|c|c|c|c|}
\hline Başlık & Pdf & $\begin{array}{l}\text { Makale } \\
\text { Görüntülenme }\end{array}$ & $\begin{array}{c}\text { Makale } \\
\text { İndirilme }\end{array}$ \\
\hline \multicolumn{4}{|l|}{ Pdf ye göre ilk 5} \\
\hline Türkiye'de Gelir Eşitsizliği ve Yoksulluk & 38212 & & \\
\hline Türkiye'de Nüfus Hareketlerinin ve İç Göçün Nedenleri & 24967 & & \\
\hline Bürokrasi Teorisi ve Yönetim & 21248 & & \\
\hline $\begin{array}{l}\text { Kent Yönetimi, Kentlileşme ve Göç: Sorunlar ve Çözüm } \\
\text { Önerileri }\end{array}$ & 16331 & & \\
\hline $\begin{array}{l}\text { Küreselleşme Sürecinde Sivil Toplum Kuruluşları ve } \\
\text { Türkiye'deki Durumu }\end{array}$ & 14664 & & \\
\hline
\end{tabular}


Makale görüntülenme ilk 5

\begin{tabular}{|c|c|c|}
\hline Türkiye’de Gelir Eşitsizliği ve Yoksulluk & 5204 & \\
\hline $\begin{array}{l}\text { Çalışma Hayatında Stres Kaynakları, Stres Belirtileri ve } \\
\text { Stres Sonuçlarının İncelenmesi Üzerine Bir Araştırma }\end{array}$ & 4660 & \\
\hline Türkiye'de Nüfus Hareketlerinin ve İç Göçün Nedenleri & 4506 & \\
\hline $\begin{array}{l}\text { Kent Yönetimi, Kentlileşme ve Göç: Sorunlar ve Çözüm } \\
\text { Önerileri }\end{array}$ & 4276 & \\
\hline Küreselleşmenin Kültürel Değerler Üzerine Etkisi & 3894 & \\
\hline \multicolumn{3}{|c|}{ Makale indirilme ilk 5} \\
\hline Türkiye'de Nüfus Hareketlerinin ve İç Göçün Nedenleri & & 31004 \\
\hline Bürokrasi Teorisi ve Yönetim & & 26396 \\
\hline Küreselleşmenin Kültürel Değerler Üzerine Etkisi & & 19922 \\
\hline Elite Theories of Pareto, Mosca and Michels & & 19798 \\
\hline Türkiye'de Sendika-Siyasi Parti İlişkileri & & 19500 \\
\hline
\end{tabular}

Tablo 6'da yer alan makalelerin görüntülenme ve indirilme sayılarını gösteren veriler incelenirken sistemde "pdf", "makale görüntülenme" ve "makale indirilme" olmak üzere üç farklı seçenek olduğu görülmektedir. Konu ile ilgili olarak 26.08.2019 tarihinde ULAKBİM DergiPark Destek biriminden bilgi talebinde bulunulmuştur. Örnek bir makale üzerinden sorulan soruya 27.08.2019 tarihinde gelen cevap şu şekildedir;

Bir makalenin DergiPark'taki https://dergipark.org.tr/iusskd/ issue/936/10563 sayfası görüntülendiğinde görüntülenme sayısı artar. Bu sayfadaki dosya tıklandiğında ya da bu sayfanın Google gibi arama motorlarına sunmuş olduğu dosya linki tıklandı̆̆ında ise indirilme sayısı artar. PDF dosyası yanında gördüğ̈̈nüz sayı (753) ile indirilme istatistiğinde görüntülediğiniz sayını (883) farklı olmasi; bu makale için bir başka dosyanın daha olduğunu, ancak ilgili dosyanın artık kullanıcılara kapalı olduğunu (kaldırıldı̆̆ını, değiştirildiğini ya da silindiğini) göstermektedir. Makale istatistikleri için ekteki görselde ${ }^{10}$ işaretlediğimiz yeri dikkate alabilirsiniz. Illgili makale için tüm görüntülenme ve indirme sayısın içerir.

Gelen cevap doğrultusunda en fazla görüntülenen makalenin “Türkiye'de Gelir Eşitsizliği ve Yoksulluk" olduğu ancak en fazla indirilen makalenin ise "Türkiye'de Nüfus Hareketlerinin ve İç Göçün Nedenleri” olduğu görülmektedir. Dergi okuyucularının/kullanıcılarının görüntülenme $10 \bigcirc 591 \pm 1.167$ görselde işaretlenen yer. 
ve indirilme sayıları bakımından ayrıntılı bir yorum yapabilmek için indirilme tarihleri ya da kullanıcı bilgileri gibi ek verilere ihtiyaç duyulmaktadır. Mevcut hali ile DergiPark sisteminden bu bilgilere erişim sağlanamamaktadır. Sisteme giriş için üyelik zorunluluğu bulunmadığından kullanıcı bilgilerine erişimin de sadece IP adresleri bazında olabileceği düşünülmektedir. $\mathrm{Bu}$ konuda sistemin işleyişi ile ilgili daha ayrıntılı çalışmalara ihtiyaç vardır.

Ancak görüntülenme ve indirilme verilerine dayanarak bu aşamada söylenebilecek olan Dergi'de yer alan hangi çalışmaların daha fazla "ilgi" gördüğüdür. Elbette bu ifadeden de "görüntülenme ve indirilme sayıları bakımından ilk 5'te yer almayan çalışmaların daha değersiz ya da ilgi görmeyen çalışmalar olduğu” gibi bir anlam çıkarılmamalıdır. Dergi'nin basılı kopya sayıları bilinmemektedir. Genel bir bilgi içeren bu veriler bir analizden ziyade mevcut durumun "resmini çekmektedir". Bu bağlamda araştırmacılar ve dizinleme çalışmaları yapan kurumlar boşlukta kalan teknik kısımların geliştirilmesine yönelik tespitler yapmaktadırlar.

Çalışma konusu ile ilgili bir tespit yapmak gerekirse başlığında ILO olan çalışmalar daha az görüntülenmiş ya da indirilmiştir.

Tablo 7

ILO İle İlgili Makaleler Bakımından Internetten Görüntülenme ve Elde Edilme Sayıları

Makale Başlı̆̆ı

Makale Makale Görüntülenme İndirilme

Makale görüntülenme ilk 5

Cumhuriyet Döneminde Türk Endüstri İlişkileri: İşçi

Sendikalarının Dünü, Bugünü

1682

Çocuk İşçiliği: Nedenleri, Boyutları ve Küreselleşen Dünyadaki

Konumu

Türkiye'de ve Dünyada Yeni Sendikal Perspektifler

1258

Ücret Sistemleri

1085

Türkiye'de Sendika-Siyasi Parti İlişskileri

1057

\section{Makale indirilme ilk 5}

Türkiye'de Sendika-Siyasi Parti İlişkileri

19500

İşçi Sendikalarının Tarihi Gelişimi (İngiltere Örneği)

Türkiye'de ' 'Zorunlu Çalışma" Uygulamaları

Çocuk İşçiliği: Nedenleri, Boyutları ve Küreselleşen Dünyadaki 
ILO ile ilgili çalışmalar kapsamında yer alan makalelerin görüntülenme ve indirilme sayıları incelendiğinde Tablo 6' da verilen görüntülenme ve indirilme sayılarının çok altında değerler olması, okuyucuların konuya olan ilgilerinin görece daha düşük düzeyde olduğunu göstermektedir. "Türkiye'de Sendika-Siyasi Parti İlişkileri” okuyucuların en fazla indirdikleri makaledir. İkinci sırada "İşçi Sendikalarının Tarihi Gelişimi (İngiltere Örneği)" çalışması gelmektedir. Burada aşırı genelleme yapmaktan da kaçınarak çalışmanın sınırları içinde sendikalarla ilgili konuların daha fazla ilgi gördüğü söylenebilir.

\section{Sosyal Siyaset Konferansları Dergisi'nde ILO}

ILO, 28 Haziran 1919 tarihli Versay Barış Andlaşması'nın 387-427. maddeleri çerçevesinde kurulmuştur. Milletler Cemiyeti'nin yanı sıra kurulan bu Teşkilât, Milletler Cemiyeti'nin feshinden sonra ortadan kaybolmamış ve Birleşmiş Milletler'in bir “uzmanlık kuruluşu” olarak varlığını sürdürmektedir (Işık, 1968: 167). Çalışma hayatıyla ilgili uluslararası asgari standartlar oluşturan ve işçi, işveren ve hükümet temsilcilerinden oluşan üç taraflı bir örgüt olan ILO, çalışma hayatına düzenlenmesi ve dünya barışının sağlanması için sosyal adaletin gerçekleştirilmesi için çalışmalar yapmaktadır. ILO; sosyal, ekonomik, hukuki, kültürel, antropolojik, uluslararası ilişkiler gibi çalışma hayatını ilgilendiren bütün konularda normlar geliştirmek, politika önerilerinde bulunmak, farkındalık yaratmak ve kamuoyu oluşturmak konusunda önemli katkılar sağlamaktadır.

Bütün ülkeler gibi, Türkiye'de de endüstri ilişkileri sisteminin organizasyonu ve işleyiş esasları oluşturulurken, ILO'nun çalışma standartları referans olarak alınanunsurların başında gelmektedir. UluslararasıÇalışma Standartları endüstri ilişkileri sistemini ve bu sistemin içinde yer alan aktörlerin davranışlarını çok yönlü olarak etkilemektedir. Hükümetler çalışma hayatı ile ilgili yasaları çıkarırken ILO standartları ile çizilen çerçeveyi esas almaktadır. Çalışma hayatının aktif taraflarını oluşturan işçi ve işveren ile bunların temsilcisi olan sendikalar, çalışma hayatına yönelik talepleri ve beklentilerinde ILO'yu ve standartlarını mihenk taşı olarak almaktadırlar. Bütün bunların ötesinde ILO, bir organizasyon olarak endüstri ilişkileri sisteminin aktörlerinin birbirleri ile olan anlaşmazlıklarında, karşı taraf üzerinde yaratacağı baskıya bağlı olarak, bir çözüm yeri olarak görülmektedir (Alper ve Kaya, 1995: 2). Ancak Alper ve 
Kaya, Türkiye'de ILO konusunun, sahip olduğu önemin aksine literatürde çok işlenen bir konu olmadığını ifade etmektedirler.

“...Daha çok genel sosyal politika ile ilgili kitapların bir bölümünü ve uluslararası sosyal politika ile ilgili çalışmaların ise ağırlıklı konusunu oluşturmaktan öteye gidememiştir. Yalnızca ILO'yu ele alan çalışma ve araştırma sayısı son derecede sinırlı kalmıştır", (Alper ve Kaya, 1995: 2).

Mevcut araştırmanın konusunu oluşturan ILO konulu makalelerin Sosyal Siyaset Konferansları Dergisi kapsamında yer alması ile ilgili olarak da benzer bir durum bulunmaktadır. Doğrudan ILO ile ilgili 26 çalışma bulunmaktadır. Bu sayı toplam çalışma sayısının \%3,1'idir.

Tablo 8

Temel ILO Sözleşmeleri

\begin{tabular}{|c|c|c|}
\hline $\begin{array}{l}\text { Sözleşme } \\
\text { No }\end{array}$ & Kabul Tarihi & Sözleşme Adı \\
\hline 29 & 1930 & Zorla Çalıştırma Sözleşmesi \\
\hline 87 & 1948 & $\begin{array}{l}\text { Sendikalaşma Özgürlüğü ve Sendikalaşma Hakkının Korunması } \\
\text { Sözleşmesi }\end{array}$ \\
\hline 98 & 1949 & Sendikalaşma ve Toplu Sözleşme Hakkı Sözleşmesi \\
\hline 100 & 1951 & Eşit İşe Eşit Ücret Sözleşmesi \\
\hline 105 & 1957 & Zorla Çalıştırmanın Yasaklanması Sözleşmesi \\
\hline 111 & 1958 & İstihdamda Ayrımcılığın Önlenmesi Sözleşmesi \\
\hline 138 & 1973 & Asgari Yaş Sözleşmesi \\
\hline 182 & 1999 & $\begin{array}{l}\text { Çocuk İşçiliğinin En Kötü Biçimlerinin Sona Erdirilmesi } \\
\text { Sözleşmesi }\end{array}$ \\
\hline
\end{tabular}

Kaynak:http://disk.org.tr/2016/05/turkiyenin-uluslararasi-calisma-orgutu-karnesi/; https:// www.ilo.org/wcmsp5/groups/public/---europe/---ro-geneva/---ilo-ankara/documents/ genericdocument/wcms_645630.pdf

1948'den 2019'a kadar geçen 71 y1lda 76 sayı olarak çıkan Sosyal Siyaset Konferansları Dergisi, 1948 - 2002 ve 2003 - 2019 olmak üzere iki alt döneme ayrılarak incelenebileceği gibi basılı ortamdan internet ortamına geçtiği 20092010 yılları öncesi ve sonrası biçiminde bir dönemleştirme de söz konusu olabilir. Dergi'nin temel ilkeleri korunmakla birlikte "bilimsel ve hakemli" dergi statüsüne geçtiği 2003 yılını esas alan ayrım derginin yazar, makale sayısı gibi bibliyometrik açıdan analizi için işlevsel olabilir. Başka bir açıdan internet aracılığıyla erişilebilir olması bilginin yayılması ve paylaşılması ile ilgili daha fazla firsat sağladığından bu ayrım altında incelenebilir. Ancak bu araştırmanın temel konusu "Sosyal Siyaset Konferansları ve Uluslararası 
Çalışma Örgütü (ILO)" olduğundan dönemlere göre Türkiye tarafından onaylanan ILO Sözleşmeleri dikkate alınarak araştırma konusu ile uyumlu bir dönemleştirme yapılmıştır. Türkiye ILO’ya 1932 yılında üye olsa da 1932-1946 arasında sadece bir sözleşme ve 1946-1959 döneminde ise 11 ILO sözleşmesi onaylanmıştır. ${ }^{11}$. Tablo 8 incelendiğinde onaylanan ILO sözleşmesi sayısının 1 (bir) olduğu 1932-1946 dönemi hariç tutulduğunda Sosyal Siyaset Konferansları Dergisi ile Türkiye ILO ilişkilerinin “yaşıt” olduğu söylenebilir.

Tablo 9

Dönemlere Göre Türkiye Tarafindan Onaylanan ILO Sözleşmeleri

\begin{tabular}{lc}
\hline Dönem & Onaylanan ILO Sözleşmesi Sayısı \\
\hline 1932-1945 Dönemi & 1 \\
1946-1959 Dönemi & 11 \\
1960-1980 Dönemi & 15 \\
1980-2015 Dönemi & 32 \\
Toplam (1932-2015) & 59 \\
\hline
\end{tabular}

Kaynak: Kutal, 1970: 186 ve http://disk.org.tr/2016/05/turkiyenin-uluslararasi-calisma-orgutukarnesi/; https://www.ilo.org/wcmsp5/groups/public/---europe/---ro-geneva/---ilo-ankara/ documents/genericdocument/wcms_645630.pdf

Yayınlanmış olan Sosyal Siyaset Konferansları dergileri ile onaylanan ILO sözleşmeleri, birlikte ele alınıp dönemleştirme yapılırken ilgili dönemde yaşanan gelişmelerin akademik yayınlara yansımasının eş zamanlı olmayacağını da kabul etmek gerekir. Ancak yine de genel çerçeve hakkında bilgi verebileceği düşünülen, araştırma kapsamındaki bu dönemler Tablo 9' da yer almaktadir.

Tablo 10

Tablo 9 Esas Alınarak Düzenlenmiş Sosyal Siyaset Konferansları Dergisi Yılları ve Sayıları

\begin{tabular}{ll}
\hline Yll & Sayı \\
\hline $1948-1956$ & Say1 1 ve Say1 8 arası \\
$1960-1978$ & Say1 91011 ve Sayı 30 aras1 \\
$1982-2012$ & Say1 31 ve Say1 69 aras1 \\
$2015-2019 *$ & Say1 70 ve Say1 76 aras1 \\
\hline
\end{tabular}

Kaynak: Sosyal Siyaset Konferansları Dergisi'nin DergiPark sisteminde bulunan dergi sayfasından alınarak araştırmacı tarafından tablolaştırılmıştır.

Not: Derginin 19482019 yılları arasında yıl boşlukları bulunmaktadır. Bunlar; 1956-1960, 19791982, 1986-1992, 1993-1995, 1995-1998, 1998-2000, 2000-2003 y1llarıdır.

*Çalışmanın hazırlandığı dönemde yayınlanmış olan son sayı 2019 yılındaki 76. Sayı’dır.

11 1919-1939 döneminde toplam olarak 67 sözleşme ve 66 tavsiye kabul edilmiştir (Kutal, 1970: 182). Türkiye'de 1932-1960 arasında onaylanan toplam sözleşme sayısı 12'dir. 1961 yilında onaylanan 3 sözleşme ile de, bu sayı ancak 15'e yükselmiştir. 1960 yılı itibarıyla ILO'nun kabul ettiği toplam sözleşme sayıs1 ise 115'dir (Gülmez, 2019: 37). 
Tablo 10'da yer alan y1llar Tablo 9 ile uyumlu olacak şekilde Dergi'nin sayı yayınlamış olduğu yıllara göre oluşturulmuştur. Bu yıllar oluşturulurken başlığında ve konusunda doğrudan ILO kelimesi olan ${ }^{12}$ çalışmalar sıralanmıştır. Tablo 8'de verilen temel sözleşmelere ilişkin olarak da "sendika", "ücret", "ayrımcılık”, "asgari yaş", "çocuk çalışan” anahtar kelimeleri kullanılarak ILO ile ilgili çalışmalar veri tabanı oluşturulmuştur. $\mathrm{Bu}$ kapsamda 140 çalışma bulunmaktadır. Bunlardan 122'si (\%87,14) makale, 17'si Konferans $(\% 12,14)$ ve 1'i $(\% 0,71)$ de olay incelemesidir. ILO ile ilgili olarak yapılan çalışmaların önemli bir bölümü tek yazarlıdır (132 adet), 4 çalışma 2 yazarlı, 1 çalışma 4 yazarlı ve 2 çalışma da 6 yazarlıdır. 6 yazarlı çalışmalardan biri panel ve diğeri de makaledir. Daha önce de belirtildiği gibi Dergi'nin yapısal özelliği gereği temelde konferans ve makaleler biçiminde çalışmalar bulunmaktadır.

\section{Sosyal Siyaset Konferansları Dergisi'nde 1948 - 1956 Yılları Arasında Yer Alan ILO Konulu Çalışmalar}

$\mathrm{Bu}$ alt dönemin özelliklerine kısaca değinmek gerekirse; Türkiye'de 1942 yılında Beveridge Raporu'nun ${ }^{13}$ yayınlanması, 1945 yılında Çalışma Bakanlığı'nın kurulması, aynı yıl İş Kazası Meslek Hastalıkları ve Analık Sigortası Hakkında Kanun'un yürürlüğe girmesi, 1946'da İşçi Sigortaları Kurumu'nun kurulması, 1949'da Emekli Sandığı'nın düzenlenmesi gibi gelişmelerden söz edilebilir (Buğra, 2010: 161). Türkiye'ye ilişkin bu küçük hatırlatmaların yanı sıra Türkiye'nin 11 ILO sözleşmesi imzaladığı bu önemli dönem ILO bakımından da 1946 yılından başlayarak bir dönüm noktası olmuştur. Birleşmiş Milletler ile yapılan anlaşma sonucu, ILO, kendi faaliyet alanına giren konularda belirlediği amaçları gerçekleştirmek için hareket serbestisine sahip uzman bir Birleşmiş Milletler kuruluşu haline gelmiştir. ILO, bu dönemde yalnızca Birleşmiş Milletler ile değil, Birleşmiş Milletler’e bağlı diğer uluslararası kuruluşlar ve bölgesel kuruluşlar ile de işbirliğini geliştirmeye yönelik teşebbüslerde bulunmuştur. $\mathrm{Bu}$ dönemde ILO takip

12 Literatürde ve veri tabanında Uluslararası Çalışma Örgütü (ILO) olarak İngilizce kısaltmanın yanı sıra Türkçe kısaltması olan UÇÖ ve geçmiş yıllara ait olan makaleler için de Milletler Arası Çalışma Teşkilatı gibi kullanımlar dikkate alınarak yapılmıştır.

13 İngiltere'de sosyal güvenlik sistemini geliştirmek amacıyla; çalışamayacak kadar hasta olanlara yönelik sağlık hizmetlerinin oluşturulması, ailelere yardım sağlanması, işsizlik sigortasının genişletilmesi, emekli aylıklarının yükseltilmesi, dullara aylık bağlanması, doğum ve ölüm durumunda tazminat ödenmesi gibi öneriler içeren, 1942 yılında Sir William Beveridge tarafından hazırlanmış plan. http://www.nedirnedemek. com/beveridge-raporu-nedir-beveridge-raporu-ne-demek, (Erişim tarihi: 19.02.2014). 
ettiği politikalarla sürekli barışı sağlamaya yönelik etkin bir rol oynamaya başlamıştır (Alper ve Kaya, 1995: 2). Ekin'e göre dönemle ilgili olarak;

“......dikkat çekici bütün bu gelişmeler içinde en önemli yasalardan birinin "Sendikalar Kanunu” olduğuna hiç kuşku yoktur. 1936 İş Kanunu Türkiye'de çalışma ilişkilerini sistematik bir düzenlemeye bağlayan ilk yasa olarak nasıl yeni bir dönemi temsil ediyorsa, 1947 Sendikalar Kanunu da bizzat çalı̧̧anların kendi örgütlerini kurmaya yönelik faaliyetlerde bulunabilmelerinin ilk yasal başlangıcını teşkil etmektedir. 1946 yılında sinıf esasına dayalı cemiyet kurma yasağının kaldırılması ite başlayan bu devre içinde, devrin siyasî iktidarl meslekî işçi örgütleri kurulmasına özel bir özen göstermiş, hatta bunların kurulması için dolaysı girişimlerde bulunmuştur" (Ekin, 1986: 43).

Türkiye'de 1936 tarihinde Türk İş Kanunu'nun kabul edilmesiyle birlikte sanayi hayatında, emek piyasasında ve işçi - işveren ilişkilerinde karşılıklı hakların kurulması ilkesi benimsenmiştir (Tuna, 1978: 4). Türkiye'de çalışma ilişkilerinde yepyeni bir dönem olarak adlandırılan bu dönemdeki gelişmeler gözönünde bulundurulduğunda, dergiyeyönelenyayınlarda ILO etkisinden çok II. Dünya Savaşı'ndan sonra Türkiye'nin demokratik bir ülke olarak Birleşmiş Milletler'e girme çabaları, 1948'de Uluslararası Çalışma Örgütü'ne tekrar katılması ve nihayet 1945'lerden itibaren çok partili dönemin başlaması gibi dönemin kendine has koşullarının etkisinin daha baskın olduğu söylenebilir. Siyasî niteliği ağır basan bu liberalleşme hareketine paralel olarak Savaş sonrası dönemde, iktisat politikasında da önemli değişikliklerin oluştuğunu görülmektedir (Ekin, 1986: 43). 1919-1939 arasındaki ilk döneminde, yalnızca "bırakınız yapsıncı" liberalizmin aşırılıklarının ve acımasız sömürünün ürünü olan sonuçlarının törpülenmesi amaçlandı. Sözleşme ya da tavsiye ile düzenlenen sorunların büyük bir çoğunluğu, "bırakınız yapsıncı" katı anlayışa alt sosyal sınır getirilmesi amacına yönelikti. Bunlar, ILO öncesi dönemde düzenlenen konferans ve kongrelerde de ele alınan ivedi çalışma ve istihdam koşullarıyla ilgiliydi. Ekonomik ve sosyal yönden güçsüz olan kişi ve kesimleri koruma amacı taşıyordu (Ekin, 1986: 33-51). Gülmez, 2013: 215-284'e göre 1919-1939 dönemi liberalizmin aşırılıklarının önlenmesi ile sosyal hakların uluslararasılaşması süreci olarak ele alınmaktadır (Gülmez, 2015: 2015-284). 
$\mathrm{Bu}$ alt dönemde ele alınan tüm çalışmalar ${ }^{14}$ yürütülmüş olan Sosyal Siyaset Konferansları sunumlarının basılı hale getirilmiş biçimleridir.

Tablo 11

Sosyal Siyaset Konferanslart Dergisi'nde 1948 - 1956 Yilları Arasinda Yer Alan ILO Konulu Çalışmalar

\begin{tabular}{|c|c|c|}
\hline Yıl & Makale Başlığı & Yazar \\
\hline 1948 & Türk İşçi Sendikalarının Karakterleri & Ferit H. Saymen \\
\hline 1949 & Ücret Sistemleri & Alfred Isaac \\
\hline \multirow{2}{*}{1950} & İşçi Sendikalarının Mahiyet ve Vazifeleri & Orhan Tuna \\
\hline & Ücretler ve Fiyatlar & Reşat Nalbandoğlu \\
\hline 1951 & Bugünkü Sovyet Sendikalizminin Nazari ve Tatbiki Esasları & Orhan Tuna \\
\hline \multirow[t]{2}{*}{1952} & $\begin{array}{l}\text { İzmir’de İşçi Sendikaları Hakkında Sosyolojik Bazı } \\
\text { Müşahedeler }\end{array}$ & Z. Fahri Fındıkoğlu \\
\hline & Milletlerarası Çalışma Teşkilatı & Bedi Süngütay \\
\hline \multirow{3}{*}{1954} & ILO'nun Tekstil İşçilerine Sağladığı Faydalar & Livio Costa \\
\hline & Amerika'da Sendikacılık Hareketleri & Leo Schachter \\
\hline & $\begin{array}{l}\text { Memleketimizde Sendikacılık Hareketlerinin Gelişmesi ve } \\
\text { İşçilerimizin Sendikalaşma Meselesi }\end{array}$ & Orhan Tuna \\
\hline \multirow{5}{*}{1955} & Asgari Ücretler & H. Arndt \\
\hline & Hayat Pahalılığ1 ve Ücretlerin Tayini & Haydar Furgaç \\
\hline & İşçi ve Sendikacıların Eğitimi & Ekmel Zadil \\
\hline & Sendikacılık ve Siyaset & Orhan Tuna \\
\hline & Türk Sendikacılığının İnkişafına Mani Olan Bazı Sebepler & Bahir Ersoy \\
\hline \multirow{2}{*}{1956} & Memleketimizde Sendikaların Üzerinde Durdukları Meseleler & Orhan Tuna \\
\hline & Türkiye Mensucat Sanayiinde Ücretler & Sabahaddin Zaim \\
\hline
\end{tabular}

Türkiye tarafından 11 ILO sözleşmesinin onaylanmış olduğu bu alt dönemde Sosyal Siyaset Konferansları Dergisi'nde de yayınlanmış olan 17 çalışma bulunmaktadır. Bu dönemde yapılmış olan çalışmalardan doğrudan "ILO" anahtar kelimesini içeren 2 çalışmaya karşılık "sendika" konulu 10 çalışma bulunmaktadır. "Ücret” konulu çalışma sayısı ise 5’tir.

ILO ile ilgili çalışmalardan ilki olan Söngütay, 1952'de 62 üyeli bir kuruluş olan ILO'nun bütün dünyada ırk, din, inanç ve cinsiyet farkı gözetmeksizin, çalışma ve yaşama şartlarını düzenlemek, sosyal güvenliği sağlamak, bu yolla barışın temellerini atabilmek amacı taşıdığını vurgulamaktadır (Söngütay, 1952: 24). İkinci çalışmada ise Costa, dünyaya yayılan dokuma sektöründe önceleri müşteri olan ülkelerin sonradan üretici konumuna geldiklerini belirtmektedir. Tekstil sektöründe dünyada yaşanan makineleşme ve ilerlemeler Türkiye'de de yaşanmaktadır (Costa, 1954: 44).

14 Metin yazımı içinde, makale, çalışma, eser vb. tanımlalar aynı anlama gelmek üzere kullanılmıştır. Derginin kendine has yapısı hangi sayıdan itibaren "hakemli dergi" statüsüne geçtiği gibi bilgiler yöntem kısmında ve ilgili tablolar altında veriştir. 
$\mathrm{Bu}$ alt dönemin ücret ile ilgili çalışmalarında da mensucat sanayi örneklendirilmektedir. "1938 ve 1950 yılları arasında karşılaştırma yapıldığında İstanbul mensucat işçisinin, Japon işçisi hariç, en düşük satın alma gücüne sahip olduğu, Peru, Şili, Brezilya, Arjantin, İtalya ve hatta Hint işçisinin daha iyi durumda olduğu tezahür etmiştir” (Zaim, 1956: 40). Ücret ile ilgili diğer çalışmalarda da ücretlerin oluşumu ve satın alma gücü ile ilişkisi ele alınmaktadır. Isaac "insanın emeğinin bedelinin ücretten ibaret olmadığı, işine ilgi ve takdir gösterildiği zaman sevinç ve memnuniyetle çalışabileceği"ni ifade edilmektedir (Isaac, 1949: 64). Nalbandoğlu ücretlerin milli gelir içindeki payının, ücret değerinin azlığı ya da çokluğunun satın alınabilecek mal ve hizmet miktarına bağlı olduğunu ve aynı zamanda maliyet unsuru olduğundan fiyatları da etkilediğini anlatmaktadır (Nalbandoğlu, 1950: 75). Arndt' 1955 'te ise asgari ücretin tanımı, belirlenmesi açıklanmış, uygulama boyutu sayısal örneklerle desteklenmiş ve ABD'de Roosevelt döneminde uygulanan ve krizden çıkışı sağlama amacı taşıyan asgari ücret uygulaması örneklendirilmiştir (Arndt, 1955: 33). "Hayat pahalılığı bugüne mahsus bir dert değildir” diyen Furgaç, 1955':51'de İstanbul'da 1954 yılında ilk kez yapılacak olan aile harcamalarının belirlenmesi anketi anlatılmıştır (Furgaç, 1955: 60).

Sendika ile ilgili ilk çalışma aynı zamanda konferanslar serisinin ilki olan Saymen'in çalışmasıdır. Çalışmada Türkiye'de sendikaların ortaya çıkışı, faaliyetleri ve yasanın kabulü süreci ve sonrasında yaşanan tartışmalar ele alınmaktadır. Sonuç kısmında dönemin sendikalarını ne devlete bağlı ne de tamamen serbest birer sendika olmayıp ikisinin ortasında özelliğe sahip olduğu, bu durumunda iş mevzuatı ile uyumlu bir durum olduğu dile getirilmektedir (Saymen, 1948: 105). Fındıkoğlu tarafından verilen konferans kapsamında da İzmir ilinde İş Kanunu sınırlarına giren işyerleri ve buralarda çalışan işçileri sayısı tablo olarak verilmiştir. Saymen'in çalışmasında yer alan tabloda kadın, erkek ve çocuk işçi sayıları coğrafi bölgelere göre yer almaktadır.

1951 yılı itibariyle İzmir'de 899 işyerinde, 26,871 erkek, 23,939 kadın ve 3290 çocuk işçi olmak üzere 54,100 işçi çalışmaktadır. Manisa'daki işyerleri ve işçiler de eklendiğinde İş Kanunu kapsamına giren 1057 işyerinde 58,398 işçi bulunmaktadır (Fındıkoğlu, 1952: 5). Çalışmada İzmir'deki sendikalar ile ilgili ayrıntılı bilgiler, örgütlenme ile ilgili sorunlar, işleyiş ve tartışmalara yer verilmektedir. 1951 yılı itibariyle İzmir' de 899 işyerinde, 26,871 erkek, 23,939 
kadın ve 3290 çocuk işçi olmak üzere 54,100 işçi çalışmaktadır. Manisa'daki işyerleri ve işçiler de eklendiğinde İş Kanunu kapsamına giren 1057 işyerinde 58,398 işçi bulunmaktadır (Fındıkoğlu, 1952: 5). İşçi eğitimi ve sendikacı yetiştirilmesi konusunda sosyal politika çalışmalarının her alanında ilk sırada yer alan Almanya ve İngiltere ile bunlara yaklaşan Amerika' daki uygulamalar üzerinden konunun ele alındığı ifade edilen çalışmasında Zadil, kapitalizmin işçileri üretim araçlarından ayırması, fabrika sistemindeki çalışma koşullarını ele almaktadır (Zadil, 1955: 122). Alt dönem içindeki sendika konulu diğer çalışmalar gibi Ersoy da sendikaların ilerlemesinin ön koşulunun işçilerin kendisi olduğu düşüncesi ifade etmektedir (Ersoy, 1955: 50).

Sendika konulu 10 çalışmadan 5'i Orhan Tuna tarafindan verilmiş olan konferanslardır. Tuna, işçilerin, çalışan sınıfların ve münhasıran çalışma güçlerinden başka hiç bir şeyleri olmayan kütlelerin bu "değişen dünya" karşısındaki durumlarının değişimi karşısında kendilerine destek olacak sendikalar içinde örgütlenmeleri ve kendilerine ait sorunları kendi güçleri ile çözmeleri gerektiği vurgulanmaktadır. Gerek bireysel gerekse kolektif olarak ancak kuvvetli olanların kendi kendine yardım imkânına sahip olacağını ifade eden Tuna, bu kendi kendine yardımın işleyebilmesi için sendikalara, fakat kuvvetli sendikalara ihtiyaç bulunmakta olduğunu savunmaktadır (Tuna, 1950: 134). Ayrıca ücret, iş kanunu düzenlemeleri, sendikalar kanunu düzenlemeleri gibi sendikaların üzerinde durduğu konuları ele alan Tuna (1956: 103). Türkiye'de 1946 y1lından itibaren beş alt1 y1l içinde 300 kadar sendika, 15 birlik ve federasyon kurulmuş ve İş Kanunu'na tâbi olarak çalışan işçilerin yaklaşık \% 30'u bu kuruluşların bünyesinde bulunmaktadır (Tuna, 1954: 61). Tuna'ya göre "İş̧̧i sınıfı kadar başka hiçbir sosyal sınıf piyasa kanunlarına olan güvenini bu derece kaybetmemiştir ancak yine de iktisadi ve sosyal sistemin değiştirilmesini amaçlayan politikalar dışında yapılacaklar da vardır". Türk sendikacılığı batı Avrupa'daki benzerlerinin yanında “emekleyen bir çocuk manzarası” göstermektedir (Tuna, 1954: 65). Tuna 1950'li yıllardaki Sovyet sendikalizminin ele aldığ çalışmasında sendikaların sınıf mücadelesinin en önemli unsuru olduğunu ifade etmektedir. Çalışmada ayrıca Sovyet Sosyalist Cumhuriyetler Birliği'nde sendikaların hukuki durumları diğer ülkelerden farklı olduğu için karşılaştırma yaparken dikkatli olmak gerektiği ifade edilmektedir (Tuna, 1951: 79). 1955 tarihinde işçiler için düzenlenen altıncı konferansın bitişini ilan ederken konferansların İstanbul Üniversitesi İktisat Fakültesi Sosyoloji ve Sosyal Siyaset Enstitüsü tarafindan 
işçiler büyük emek ve çabalarla gerçekleştirildiğini ancak sendikacıların yeterli ilgiyi göstermediğini belirtmektedir (Tuna, 1955: 121).

Türkiye'nin 1932-1945 döneminde 67 sözleşmeden sadece bir tanesini15 onaylamış olması ILO’ya karşı ilgisizliğin bir göstergesidir. Bu durumun ILO’ya karşı faşist ülkelerden gelen eleştirilerin Türkiye'yi olumsuz etkilemesi, tek partili siyasal düzen, ILO’nun gelişmekte olan ülkelerin milli kalkınma sorunlarına odaklanmaktan çok sanayileşmiş ülkelerin sosyal sorunların ağırlık vermesi gibi nedenleri bulunmaktadır (Kutal, 1970: 185).

Türkiye'de bu dönemde özgür sendikacılık olmadığından Uluslararası Çalışma Konferanslarına ilgi gösterilmemiş, işbirliği gösterilememiş dolayısıyla da sözleşmelerin onaylanması yetersiz kalmıştır. 1945 yılından itibaren mevcut şartlarda önemli değişiklikler olmuştur. Bir yandan ILO faaliyetini daha çok az gelişmiş ülkelere doğru yöneltmeğe başlamış, öte yandan da Türkiye'de sendikaların serbestçe kurulmasına izin verilmiş, Çalışma Bakanlığ kurulmuş, işçilerle ilgili birçok kanun kabul edilmiştir (Kutal, 1970: 185).

1946-1958 döneminde sadece 1946 yılında üç sözleşme birden onaylanmıştır. ${ }^{16}$ Aynı ilgi 1951 yılına kadar devam etmiştir. Çalışma Bakanlığı Kuruluş Kanununda ILO ile ilişkileri düzenleyecek bir organa açıkça yer verilmiştir. Böylece 1951 sonuna kadar 6 y1llık dönem içinde onaylanan sözleşmelerin sayıs1 9'u bulmuştur ${ }^{17}$

1952-1958 Türkiye'de asgari ücret uygulamasının başladığı, basın mesleğinde çalışanlar ve gemi adamları ile ilgili özel yasaların kabul edildiği, sosyal sigortaların nispeten genişlediği yıllardır. Ancak bu dönemde 1 sözleşme bile onaylanmamıştır (Kutal, 1970: 186).

\section{Sosyal Siyaset Konferansları Dergisi’nde 1960 - 1978 Yılları Arasında Yer Alan ILO Konulu Makaleler}

Türkiye'de 1961 Anayasası ekonomik ve sosyal sonuçlarıyla bir bütün olarak, özellikle endüstri ilişkileri sisteminin çağdaş gelişmelere ayak uydurması yönünden bir başlangıçtır (Ekin, 1986: 46). 1961 Anayasası ülkenin

1545 Sayılı Sözleşme

1642,14 ve 34 sayılı Sözleşmeler

$1780,88,2,81,98$ ve 96 sayılı Sözleşmeler 
ekonomik ve sosyal kalkınmasını plânlı gelişmeye bağlarken, ayrıca çalışma hayatı ile ilgili temel hakları da Anayasa güvencesi altına almıştır. Özellikle çalışma, çocuk, genç ve kadınların korunması, dinlenme, âdil ücret, sendika kurma, toplu sözleşme ve grev hakkı, sosyal güvenlik, sağlı ve konutla ilgili koruyucu Anayasa hükümleri bu haklar arasında sayılabilir. Bu gelişmeler içinde "Devlet Plânlama Teşkilâtı" kurulmuş ve karma ekonomide 1963 yılından itibaren kısa, orta ve uzun devreleri kavrayan plân uygulamasına geçilmiştir. Bu dönemde ikinci "Sendikalar Kanunu" (1963) birincisinden farklı olarak “Toplu İş Sözleşmesi, Grev ve Lokavt Kanunu” ile (1963) birlikte çıkarılarak demokratik endüstriyel ilişkiler sisteminin işleyebilmesinin temel koşulları hazırlanmıştır (Ekin, 1986: 47).

Bu alt dönem Türkiye'de Boratav tarafından yapılan ve iktisat tarihi ile ilgili dönemlendirmede “İçe Dönük, Dışa Bağımlı Genişleme: 1962-1976” ile yakın tarihlere denk gelen bir dönemdir. 1960'lar sonrasında hazırlanan ilk kalkınma planı olan Birinci Beş Yıılık Plan'da yurtiçi yatırımların arttırılarak sanayi sektörünün büyümesinin hedeflendiği ithal ikameci stratejinin gerekliliğinin savunulduğu bu dönemde ücretli ve maaşlı grupların göreli durumu düzelmiştir (Boratav, 1988: 93). Tarım dışı gelirler içinde ücretli işgücü ile sermaye paylarının dışında kalan üçüncü grup "marjinal” faaliyetlerde küçük üreticilik ve küçük hizmetlerde varlığını sürdürmektedir. 1970 sonralarında yaşanan toplumsal ve siyasi bunalım ile birlikte hızla yükselen enflasyon ve döviz darboğazları, Türkiye Ekonomisi'nde 24 Ocak İstikrar Tedbirleri'nin alınmasını zorunlu hale getirmiştir (Güçlü-Bilen, 1995: 162).

Tablo 12

Sosyal Siyaset Konferanslart Dergisi'nde 1960 - 1978 Yilları Arasinda Yer Alan ILO Konulu Çalışmalar

\begin{tabular}{lll}
\hline Yıl & Makale Başlı̆̆ı & Yazar \\
\hline \multirow{2}{*}{1960} & Amerikan Sendikaları ve Amerika'nın Dış Siyaseti & John Windmuller \\
\cline { 2 - 3 } & Amerikan Sendikalarının Prodüktivite Mevzuundaki Davranışları & John Windmuller \\
\cline { 2 - 3 } & Amerikan Sendikalarının Siyasi Faaliyetleri & John Windmuller \\
\hline \multirow{2}{*}{1961} & $\begin{array}{l}\text { Sendikaların Verimliliğe Tesiri ve Bu Yönden iktisadi Gelişme } \\
\text { Üzerine Oynadığı Rol }\end{array}$ & Sabahaddin Zaim \\
\cline { 2 - 3 } & \begin{tabular}{l} 
Mülletler Arası Çalışma Teşkilatının Teşrii Faaliyeti ve Türkiye Ücret İstatistikleri ve Ücret Tahavvülleri \\
\cline { 2 - 3 }
\end{tabular} & Ferit Saymen \\
\hline Milletlerarası Çalışma Teşkilatı ve Az Gelişmiş Memleketler & K. Jain \\
\hline
\end{tabular}




\begin{tabular}{|c|c|c|}
\hline \multirow{10}{*}{1962} & Anayasa Tasarısında Sendika Hürriyeti & Ferit Saymen \\
\hline & Sendika Hürriyeti & Metin Kutal \\
\hline & Sanayide Beşeri Münasebetler Bakımından Sendikaların Önemi. & Frank Miller \\
\hline & Sendika İçi Demokrasi & Frank Miller \\
\hline & Sendikacılığın Dünü ve Bugünü & Orhan Tuna \\
\hline & Sendikalar ve Siyasi Faaliyet & Paul Hays \\
\hline & Sendikaların Dâhili İdaresi & Bahir ERSOY \\
\hline & Sendikaların Mesleğe Yönetim ve Eğitim Mevzularındaki Rolleri & Sabri Tiğlı \\
\hline & Sendikaların Milli Gelirin Dağılışına ve İşçi-Gelir Payına Tesiri & Sabahaddin Zaim \\
\hline & $\begin{array}{l}\text { Türkiye'de İşveren Sendikalarının Gelişmemesi Sebepleri ve Bu } \\
\text { Konuda Alınması Gereken Tedbirler }\end{array}$ & Osman Kermen \\
\hline 1963 & Ziraat işçilerinin Sendikalaşması & Gülten Kazgan \\
\hline \multirow[t]{6}{*}{1964} & İsrail’de Sendikacılık Hareketleri ve Histardut Teşkilatı & Ekmel Zadil \\
\hline & $\begin{array}{l}\text { ABD’de Basın Sanayiinde Fikir İşçileri ve Bunların Sendikacılık } \\
\text { Meseleleri }\end{array}$ & Charles Hulten \\
\hline & Asgari Ücret ve Bazı Meseleleri & Metin Kutal \\
\hline & Türk Sendikacılığında Yeni Ceryan ve Gelişmeler & Bahir Ersoy \\
\hline & Türkiye'de Sendikalizmin Gelişmesi ve İktisadi Hayata Tesiri & İsmail Topkar \\
\hline & Ücretler ve Sosyal Yardımlar Tatbikatı & Kamil Oba \\
\hline \multirow[t]{6}{*}{1965} & Az Gelişmiş Memleketlerde Sendikacılık & Walter Galenson \\
\hline & En Fazla Temsil Kabiliyetini Haiz Sendika Mefhumu & Metin Kutal \\
\hline & Ereğli Kömür İşçileri ve Sendika Faaliyetleri & Mehmet Alpdündar \\
\hline & Sendikalar ve Prodüktivite & Nusret Ekin \\
\hline & $\begin{array}{l}\text { Sovyet Rusya'da Sendikalar İle Devlet Arasındaki Münasebetler- } \\
\text { in Gelişme Seyri }\end{array}$ & Nevzat Yalçıntaş \\
\hline & Türkiye’de Petrol Sanayiinde Sendikacılık Faaliyetleri & Ziya Hepbir \\
\hline \multirow[t]{2}{*}{1966} & İngiliz İşçi Sendikalarının Siyasi Faaliyetleri & Rüçhan Işık \\
\hline & $\begin{array}{l}\text { Türk Sendikacıllğında Merkezileşme Temayülü ve Muhtemel } \\
\text { Neticeleri }\end{array}$ & Toker Dereli \\
\hline \multirow[t]{4}{*}{1968} & Milletlerarası Çalışma Sözleşmelerinin Türk Mevzuatına Tesiri & Rüçhan Işık \\
\hline & Gelişen Ülkelerde Sendikalar ve Siyaset & Bruce H. Millen \\
\hline & Sendikacıllğın İktisadi Açıdan Tahlili & Robert Macdonald \\
\hline & Türkiye’nin İktisadi Gelişmesinde Ücret Siyasetinin Önemi & Sabahaddin Zaim \\
\hline \multirow[t]{4}{*}{1969} & $\begin{array}{l}\text { Devlet Personeli (Memur) Sendikalarının Hukuki Esasları ve } \\
\text { Sınırları }\end{array}$ & Metin Kutal \\
\hline & Kamu Sektöründe Sendikalar, İş Uyuşmazlıkları ve Grevler & Engin Ünsal \\
\hline & İşçi Sendikası Üyeliğinin Şartları & Nahit Okay \\
\hline & Türkiye'de Sendikacılık ve Sendikalarımız & Orhan Tuna \\
\hline \multirow[t]{4}{*}{1970} & İşçilerin Sendika Faaliyetlerine İştiraki & N. Sheth \\
\hline & Gelişmiş Ülkelerde Sendikaların Günümüzdeki Bazı Meseleleri & Orhan Tuna \\
\hline & Sendikacı Gözüyle Sosyalist Blok & Sedat Ağralı \\
\hline & $\begin{array}{l}\text { Uluslararası Çalışma Teşkilatının Yasama Faaliyeti ve Türkiye } \\
\text { Cumhuriyetinin Durumu(1919-1969) }\end{array}$ & Metin Kutal \\
\hline 1971 & Türkiye’de Sendika Temsilciliği Müessesesi & Suphi Okay \\
\hline \multirow[t]{3}{*}{1972} & Montaj Sanayiinde İstihdam ve Ücretler & Mükerrem Hiç \\
\hline & Partiler üstü Politika ve Türk Sendikacılığg & Erdoğan Balc1 \\
\hline & $\begin{array}{l}\text { Sendikalar Kanununda Yapılan Değişik ve Anayasa Mahkemes- } \\
\text { inin İptal Kararı }\end{array}$ & Suphi Okay \\
\hline
\end{tabular}




\begin{tabular}{lll}
\hline & Türk Sendikacılığında Sosyal Demokrasi Hareketi & Orhan Tuna \\
\hline & Türk Sendikacılığında Sosyal Demokrasi Hareketi & Özkal Yici \\
\hline 1974 & İşveren Sendikalarının Doğuşu ve Gelişmesi & Rafet İbrahimoğlu \\
\hline & Sendika Plüralizmi ve Dayanışma Aidatı & Orhan Tuna \\
\hline 1976 & Milli Ücret Politikasının Esasları, Sosyal ve Ekonomik Etkileri & Süreyya Hiç \\
\hline & $\begin{array}{l}\text { Türkiye İşveren Sendikaları Konfederasyonunun Endüstri } \\
\text { İlişkileri Sistemiyle İlgili Yeni Önerileri }\end{array}$ & Kubilay Atasayar \\
\hline 1977 & Sendika Üyelik Ödentisinin İşçinin Ücretinden Kesilmesi & Metin Kutal \\
\hline 1978 & Çalışma Organizasyonlarının Doğuşu & Orhan Tuna \\
\hline
\end{tabular}

1960-1978 alt döneminde 58 çalışma bulunmaktadır. Bu çalışmalardan doğrudan "ILO" anahtar kelimesini içeren 5 çalışmaya karşılık "sendika" konulu 46 çalışma bulunmaktadır. "Ücret" konulu çalışma sayısı ise 6, “sendika ve ücret” anahtar kelimelerini birlikte içeren çalışma sayısı 2'dir.

$\mathrm{Bu}$ çalışmalardan ücret konusu ile ilgili olanlar genel olarak ücretlerin belirlenmesi, ücret endekslerinin oluşturulmasına değinilmiştir. Örneğin; ücret istatistikleri ve istatistiklerin eksik yönlerini anlatan Gürtan, net ücretler üzerinden hesaplama yapmanın daha sağlıklı olduğu ancak net ücretler hakkında veri bulunamadığını ifade etmektedir (Gürtan, 1961: 29).

ILO ile doğrudan ilgili çalışmalardan olan Işık, 1 Haziran 1967 tarihinde Uluslararası Çalışma Sözleşmeleri'nin sayısının 126'ya yükseldiğini belirtmektedir. Aynı tarihte Türkiye 18 sözleşme onaylamıştır. $\mathrm{Bu} 18$ sözleşmeye karşılık aynı tarihte Bulgaristan 74, Küba 65, ABD 7, Kanada 24, İsviçre 31, Arjantin 456, Yunanistan 35, Cezayir 42, Kenya 26, İran 5, Irak 32, Rusya 22, Gana 34 sözleşme onaylamıştır. Onaylanan sözleşmelerin sayısındaki yükseklik bu ülkelerde çalışma şartlarının çok iyi olmasının sonucu olmadığı gibi, ABD, Kanada ya da İsviçre gibi ülkelerce az sayıda sözleşmenin onaylanmış olması da bu ülkelerde iş mevzuatının uluslararası normların çok altında olduğunu göstermemektedir (Işık, 1968: 168). ILO’nun yasama faaliyetinin gerçek başarısı, kabul edilen tavsiye ve sözleşmelerin sayısı ile değil, üye devletlerin bunlara karşı gösterdiği ilgiyle ölçülmektedir (Kutal, 1970: 184). Dünyada farklı bölgelerin onay sayısı arasında da geniş farklar bulunmaktadır. Örneğin Batı Avrupa ülkeleri için ortalama tasdik sayısı 45'i bulduğu halde, Doğu Avrupa için bu ortalama 39'dan ibaret kalmakta, Amerika ülkelerinde 31'e, Afrika'da 23'e, Orta Doğuda 19'a, Asya'da ise 16'ya düşmektedir. Onay sayısı bakımından da sözleşmeler arasında önemli farklar bulunmaktadır. 
4-25 Haziran 1969 tarihleri arasında 116 ülkenin katılması ile Cenevre'de toplanan 53. Uluslararası Çalışma Konferansı bütün dünyada olağanüstü bir ilgi ile karşılanmıştır. İşçi-işveren ve hükümet delegelerinin katılması ile toplanan bu seneki konferansta birçok devlet başkanı, ünlü politikacı veya sendikacı söz almışlar, sosyal barış alanında elde edilen gelişmelerden bahsetmişlerdir.

ILO’nun1969 yılındaki konferansına karşı gösterilen bu özel ilginin sebebi, söz konusu dönemde ILO'nun 50. yılını doldurmuş olmasıdır. ILO'nun yasama faaliyeti genellikle iki döneme ayrılarak incelenmektedir. Bunlardan birincisi 1919-1939 dönemini kapsamakta, ikincisi ise 1944 ten 1969'a kadar uzanmaktadır. Arada kalan 1940-1943 yıllarında ise ILO, İkinci Dünya Savaşı yüzünden faaliyetine ara vermek zorunda kalmıştır (Kutal, 1970: 21).

1959-1969 dönemi Türkiye açısından uluslararası çalışma sözleşmelerinin onaylanması bakımından 1946-1958 döneminden farklıdır. 1960 yılında kabul edilen sözleşmelerin hem sayı itibariyle, hem de konuları bakımından tatminkâr oldukları söylenebilir (Kutal, 1970: 189).

Ancak 1961 yılından itibaren onay faaliyeti yeniden kısır bir döneme girmiştir. Bu dönemde Türk iş hukuku önemli kaynaklarla beslenmiştir. T.C. Anayasası olmak üzere çalışma hayatını ilgilendiren birçok kanun kabul edilmiştir. Grev ve lokavt yasaklarının kaldırılması, özgür sendikacılığın, toplu sözleşme hakkının işçi ve işverenlere tanınması, birçok yetersiz yönlerine rağmen memurlara ilk defa örgütlenme hakkının verilmesi, işçi sigortalarından sosyal sigortalara geçiş bu dönemde gerçekleştirilmiştir. Yeni kanun tasarılarının hazırlanmasında geniş ölçüde uluslararası çalışma sözleşmelerinden yararlanılmasına rağmen 1966 yılına kadar geçen beş yıl içinde hiç bir sözleşmenin onaylanmamış, 1966 yılından sonra onaylanan 4 sözleşme ile onaylanan sözleşme sayısı 20 olmuştur (Kutal, 1970: 189). Kutal'a göre;

"Ellinci yılını doldurmuş bulunan ILO zamanla ortaya çıkan yeni şartlara uyum konusunda büyük bir başarl göstermiş ve kendini bütün dünyaya kabul ettirmiştir. 1989 Nobel Barış ödülünün Teşkilâta verilmesi bu hususu açıkça göstermektedir. Teşkilâtın bundan sonra da aynı önemi taşıyacağına, hattâ sosyal barış uğrunda daha faal bir döneme gireceğine muhakkak nazariyle 
bakılmaktadır. Buna karşılık memleketimizin Teşkilâtın faaliyetine gerekli ilgiyi gösterdiğini, özellikle sözleşmelerin tasdiki hususunda ciddi bir gayret sarf ettiğini söylemeye maalesef imkân yoktur. T.C. nin Teşkilât bünyesinde kendisine lâyık olan yeri daha iyi alabilmesi için sosyal barışın temelini teşkil eden işçi-işveren ve hükümet Ölçüsünün sıkı işbirliğine ve yasama organının yakın ilgisine ihtiyaç vardır” (Kutal, 1970: 198).

Bu dönemdeki ILO ile ilgili çalışmalardan Saymen (1961); ILO'nun faaliyetleri ile Sözleşme ve Tavsiyelerinin kabulü mekanizması ve bu uluslararası standartların ulusal iş mevzuatı üzerindeki etkilerinden söz etmektedir. Jain (1961) adıyla yayınlanan eser ise ILO Yakın ve Orta Doğu Faaliyet Merkezi Müdürü olan Jain tarafından verilen konferansın Dereli tarafından Türkçe'ye çevrilmiş biçimidir. ILO'nun üye devletlerle yakın işbirliği içinde bulunmakta olduğu ve bu işbirliğinin türlerinin anlatıldığ çalışmada işbirliği kapsamında yapılan konferanslar, kooperatifler, mesleki ve teknik eğitim ile ilgili konular örneklendirilmiştir.

Tuna (1978:1) çalışma organizasyonlarının doğuşu ile ilgili olarak tarihsel süreci Sanayi Devrimi'ni başlangıç olarak kabul ederek anlatmaktadır. 1800'lü yıllardan başlayan düzenlemeler günümüzün modern iş mevzuatlarına geçişin temellerini oluşturmaktadır. Kendi ifadesiyle;

"Emeğin korunmastyla ilgili modern mevzuat Sanayi Devrimi sonrasında Ingiltere'de ortaya çıkmıştır. İlk kanun 1802 yılında sanayide çalışan çocukların korunması ile ilgilidir. Pamuklu ve yünlü tekstil endüstrisinde gece çalışmaları yasaklanmış olan çocukların gündüz çalışma süreleri ise en çok 12 saat olarak sınırlandırılmıştır. 1819 yılında çıkarılan başka bir kanun ile 9 yaşına basmamış bulunan çocukların pamuklu iplik fabrikalarıla dokuma tezgâhlarında çalıştırılmalarını tamamen ve 9-16 yaşları arasında bulunan çocukların ise gece çalıştırılmaları yasaklamış ve gündüz çalışmalarım 12 saat ile sinırlandırılmıştır. Almanya'da da 1839 yılında kabul edilen bir Kanunla 9 yaşına basmamış çocukların fabrikalarda istihdamı yasaklanmış, 9-12 yaşlan arasında bulunan çocuklar için 10 saatlik iş günü rejimi kabul edilmiş, ayrica gece ve Pazar çalışmaları ortadan kaldırılmıştır” (Tuna, 1978: 1). 
$\mathrm{Bu}$ alt dönemde yer alan ve Tablo 12'de verilen çalışmalardan ILO ile ilgili olanlar literatür özeti biçiminde verilmiştir. Genel olarak bakıldığında bu alt dönem tek bir anahtar kelime ile ifade edilecek olursa bu kelime "sendikacılık" olmalıdır.

\section{Sosyal Siyaset Konferansları Dergisi'nde 1982 - 2012 Yılları Arasında Yer Alan ILO Konulu Çalışmalar}

Ekin'in de belirttiği üzere 1980'lerden sonra Türkiye' de endüstri ilişkilerinin karşılaştığı sorunlar ve bunları etkileyen iktisadî ve sosyal faktörler ayrı bir incelemenin konusudur. Bu dönem sisteminin dışından gelen ağırlıklı olarak iktisadi faktörlerin olumsuz etkisinin yoğun olarak hissedildiği işsizlik artışıyla, geçim sıkıntısı ve hayat pahalılığı yanında gelir dağılımının da sürekli bozulduğu bir dönemdir (Ekin, 1986: 48).

1970'li yılların sonundan itibaren derinleşen iktisadi ve sosyo-politik kriz sonucunda planlama bir kenara birakılarak ekonomide kısa süreli istikrar programına geçilmiş, 24 Ocak 1980 kararlarının getirdiği ve günümüze kadar süren neo-liberal atmosfer içinde yeni beş y1llık planlar gerçekleştirilmişse de ekonomiyi yönlendirici bir unsur olarak planlama etkinliği kaybedilmiştir. 1980 sayımlarında toplam sınai işyerlerinin \% 95'i 10 kişiden az işçi çalıştırmakta ve bu işyerlerinin sınai katma değer içindeki payı \% 10 iken çalışan oranı \% 40’1 bulmaktadır. Bu durum imalat sanayiinde işgücü verimliliğinin düşük olduğuna işaret etmektedir (Soyak, 1999: 167).

Türkiye'de gelir bölüşümü, özellikle 1980'li y1llarda büyük ölçüde bozulmuştur. Bu durum, sadece fonksiyonel gelir bölüşümünü değil, sektörel, bölgesel ve kişisel bölüşümü kapsayacak şekilde genellik kazanmıştır. 1980 yılı Türkiye'de bölüşüm ilişkilerinde yeni bir dönemdir. 1977-1980 y1llarını kapsayan kriz, 1980 yılında 24 Ocak kararları ve 12 Eylül Askeri Darbesi ile son bulmuş ve ekonomi 1981 yılında artık yeni bir düzenleme biçimine geçmiştir. Bu yeni model, 1960'lı yıllarda başlayıp 1976'da son bulan "içe dönük, dışa bağımlı" gelişim biçiminden köklü biçimde ayrılmaktadır (Boratav, 1997: 161). İç talebe dayalı birikim modelinin ömrünü tüketmesiyle yerine inşa edilmeye başlanan ihracata dönük dışa açılma modeli bunun temelinde yatmaktadır (Sönmez, 2001: 15). 
Bu dönemde "üçüncü sendikalar" (1983) ve "ikinci toplu pazarlık yasalarıyla" (1983) da bu düzenin yeni endüstri ilişkileri belirlenmiştir (Ekin, 1986: 48).

1992 yılında yeni bir yasa çıkarılmamış olmasına karşın çok önemli bazı konularda ya yasa taslakları hazırlanmış, ya da bu alanda önemli girişimler yapılmıştır. Gerçekten işsizlik sigortası ve Türkiye İş Kurumu ile ilgili yasa taslakları hazırlanarak kamuoyuna açıklanmış; 2821 ve 2822 yasalarında değişiklikler yapılması, memur (kamu personeli) sendikacılığının yasal çerçevesinin çözülmesi, nihayet kıdem tazminatının bir sandıktan karşılanması ile ilgili çalışmalar sürdürülmüştür (Kutal, 1995: 12). 1988 yılından itibaren dernek statüsünde de olsa kurulan Kamu Görevlileri Sendikaları 1995 yılında Anayasa'da yapılan bir değişiklik ile yasal hale gelmiştir (Önsal, 2010: 48).

Türkiye ekonomisi 1994 yılında kriz yaşamış ve bunu takiben 5 Nisan'da Ekonomik Önlemler Uygulama Planı açıklanmıştır (Önsal, 2010: 47). Aynı yıl ILO’nun 'Hizmet İlişkisine İşveren Tarafından Son Verilmesi Hakkında 158 Sayılı Sözleşmesi” kabul edilmiştir. Bu sözleşmeye uyum sağlamak üzere "İ̧̧ Güvencesi”ne ilişkin yasal değişikliklerin yapılması zorunluluğu doğurmuş, 2002 yılının Ağustos ayında bu amaçla 4773 sayılı yasa çıkarılmıştır.

2008 krizi dönemin dikkat çekici ekonomik gelişmesi olarak bu dönemi ekonomik bakımdan şekillendirmiştir. 12 Eylül 2010 Halk Oylaması öncesinde, 53. maddeye 1995 'te konulan üçüncü fikra ile memurlara İdare'yle "toplu görüşme” imkânı sağlanmıştır (Mahiroğulları, 2011: 82). Bu alt dönemde 2009 sonunda başlayarak 2010 yılına sarkan uzun süreli Tekel Eylemleri (Man, 2011), 2011'den itibaren Suriye'den Türkiye'ye yönelen kitlesel göç dalgası gibi gelişmeler yaşanan yoğun gündemden örnekler olarak verilebilir.

ILO normları açısından Türkiye'de sendika özgürlükleri ve yeni yasa taslağının değerlendirildiği çalışmada Kutal (2008: 215-235) geçmişte mevzuatımızda yapılan çeşitli yasal ve Anayasal değişiklikler sayesinde eleştirilerin bir kısmı çözüme kavuşturulmuş olduğunu ancak bazı konularda eleştirilerin devam ettiğini vurgulamaktadır. 
Tablo 13

Sosyal Siyaset Konferansları Dergisi'nde 1982 - 2012 Yilları Arasinda Yer Alan ILO Konulu Çalışmalar

\begin{tabular}{|c|c|c|}
\hline Yil & Makale Başlığı & Yazar \\
\hline \multirow{4}{*}{1982} & Çalışma Hayatında Çocuk ve Gençler & Kenan Tunçomağ \\
\hline & Kamu Görevlileri Sendikacılığı ile İlgili Başlıca Görüşler & Bengü Dereli \\
\hline & Ücret Politikası, Verimlilik ve Sanayileşme & Ömer Aksu \\
\hline & $\begin{array}{l}\text { Yeni Sendikalar Kanunu Düzenlenirken Sendikaların Denetimi ile } \\
\text { İlgili Öneriler }\end{array}$ & Toker Dereli \\
\hline 1983 & Toplu Sözleşmelerde Değişken Ücret Uygulaması & Sabahaddin Zaim \\
\hline \multirow{2}{*}{1984} & $\begin{array}{l}\text { 12-18 Yaş Arası Çalışan Çocuklar İçin Bölgesel Bir Analiz Örneği: } \\
\text { Bursa }\end{array}$ & $\begin{array}{l}\text { Kuvvet Lordoğlu, } \\
\text { Tahir Baştaymaz }\end{array}$ \\
\hline & $\begin{array}{l}\text { Sendikalar Yasa Tasarısında İşçi ve İşveren Kuruluşlarının Faaliyeti } \\
\text { - Gelir ve Giderleri- Denetimi }\end{array}$ & Metin Kutal \\
\hline 1992 & İşçi Sendikalarının Tarihi Gelişimi (İngiltere Örneği) & İbrahim Kazak \\
\hline 1993 & ABD'de Sendikaların Geleceği & Marcus Sandver \\
\hline \multirow{4}{*}{1998} & Türkiye'de “"Zorunlu Çalışma"” Uygulamaları & $\begin{array}{l}\text { Süleyman } \\
\text { Özdemir }\end{array}$ \\
\hline & AB'de Çocuk İstihdamı & Nilgün Tunçcan \\
\hline & $\begin{array}{l}\text { Endüstri İlişkileri Boyutlarıyla Uluslararası Andlaşmalar ve Tür- } \\
\text { kiye }\end{array}$ & Ahmet Selamoğlu \\
\hline & Küreselleşme, Rekabet Gücü ve Sendikacılıkta Yeni Eğilimler & Nusret Ekin \\
\hline \multirow{3}{*}{2000} & Asgari Ücretin Vergilendirilmesi & Ömer Bosnalı \\
\hline & $\begin{array}{l}\text { Çocuk İş̧iliği: Nedenleri, Boyutları ve Küreselleşen Dünyadaki } \\
\text { Konumu }\end{array}$ & Nilgün Tunçcan \\
\hline & Sanal İşletmelerde Ücretleme Fonksiyonu & Halil Zaim \\
\hline \multirow{7}{*}{2003} & Türkiye'de Sendika-Siyasi Parti İlişkileri & $\begin{array}{l}\text { Adnan } \\
\text { Mahiroğulları }\end{array}$ \\
\hline & $\begin{array}{l}\text { TİSK Genel Sekreteri Bülent Pirler’in Dünyada ve Türkiye’de } \\
\text { Çocuk İşgücüne İlişkin Görüş ve Önerileridir }\end{array}$ & Bülent Pirler \\
\hline & $\begin{array}{l}\text { Türkiye’de Kamu Çalışanlarının Sendikalaşma Çabaları ve } \\
\text { Sorunları }\end{array}$ & $\begin{array}{l}\text { Abdurrahman } \\
\text { Benli }\end{array}$ \\
\hline & $\begin{array}{l}\text { Katılımcı Uygulamalarına Sendikaların Etkisi Takım Çalışması } \\
\text { Boyutuyla Almanya ve İngiltere Örneği }\end{array}$ & Deniz Kağnıcıŏ̆lu \\
\hline & $\begin{array}{l}\text { Çocuk İstihdamı Konusunda ILO Normları ve ILO-Türkiye Cum- } \\
\text { huriyeti İlişkileri }\end{array}$ & Gülay Aslantepe \\
\hline & $\begin{array}{l}\text { Türk İş Mevzuatında İş Güvencesi Sorunu ve Hazırlanan Yasa } \\
\text { Tasarısının Esasları }\end{array}$ & Savaş Taşkent \\
\hline & Türkiye’de Kamu Görevlilerinin Sendikal Örgütlenme Hakları & Metin Kutal \\
\hline \multirow{8}{*}{2004} & Cumhuriyetin 80. Yılında Türk Sendikacılığ 1 & Musa Çam \\
\hline & Cumhuriyetin 80. Yılında Türk Sendikacılığı & Salim Uslu \\
\hline & Dünden Bugüne Kamu Kesiminde İstihdam ve Ücretler & Arif Kapanoğlu \\
\hline & Cumhuriyetin 80. Yılında Türk Sendikacılığı & Alparslan Işıklı \\
\hline & Cumhuriyetin 80. Y1lında Türk Sendikacıllı̆ & Çetin Altun \\
\hline & Cumhuriyetin 80. Y1lında Türk Sendikacılığ1 & Refik Baydur \\
\hline & Emek Piyasalarını Düzenleyen Uluslararası Normlar & Ali Sayın \\
\hline & Uygun İş Bağlamında Çalışan Yoksullar & Recep Kapar \\
\hline
\end{tabular}


Turizm Sektöründe Uluslararası Çalışma Örgütü Normlarının Önemi ve Bu Normların Çalışma ve Sosyal Güvenlik Bakanlığı,

UÇO Türkiye Temsilciliği ve Turizm Bakanlığg Tarafından

Değerlendirilmesine Yönelik Bir Araştırma
Mithat Dinçer,

Füsun İstanbullu

Dinçer, Suna

Muğan Ertuğral,

Türkan Günay

Turan, Arif

Güngör, Neyir

Tekeli

Tolga Öcal

Sendikal Kimlik

Sayım Yorgun

Sendikaların Örgütlenme Sorunları ve Çözüm Arayışları

Ersin Kavi

Çocuk İstihdamı Açısından Sosyal Sorumluluk Standardı

Mustafa Delican

2006 Cumhuriyet Dönë, Bugünü

Çalışma Hayatında Özürlülere Karşı Ayrımcılık

Sivil Toplum Düzeninde Sendikaların Geleceği

Sayım Yorgun

Sayım Yorgun

"Performansa Dayalı Ücret" Uygulamasının Doktor Memnuniyeti

2007 Üzerindeki Etkileri

Türkiye'de Asgari Ücretle İlgili Sorunlar

Halil Zaim

Türkiye'de ve Dünyada Yeni Sendikal Perspektifler

Türkiye'de Sendikaların Özelleştirme Yaklaşımları

Metin Kutal

Mustafa Öztürk

Faruk Taşçı

Uluslararası Çalışma Örgütü'nün Türkiye'ye İlk Teknik Yardım

Faaliyetleri Çerçevesinde 'Yakın ve Orta Doğu Çalışma

Enstitüsü'nün Kuruluşu ve İstanbul Dönemi Faaliyetleri (1955 -

Erdem Cam

2008 1972)

Üst Düzey Yöneticilerin Ücretlendirilmesi ve Türkiye'deki

Uygulamaların Tespitine Yönelik Bir Araştırma

Uluslararası Çalışma Örgütü (ILO) Normları Açısından Türkiye'de

Sendika Özgürlükleri ve Yeni Yasa Taslağının Değerlendirilmesi.

Küreselleşme Sürecinde İnsana Yakışır İş

Eğitim Düzeyi-Ücret İlişkisi ve Türkiye'de Adalet ve Eğitim Sektörü Üzerine Bir Değerlendirme

Özel İstihdam Büroları: Türkiye Örneği

2010 Çin Endüstri İlişkileri ve 1980 Sonrası Dönemde Yaşanan

Dönüşümler

2011 Anayasa Değişikliği ve Çalışma Yaşamına Yansımaları-Açılış

Konferans1

Anayasa Değişikliği ve Çalışma Yaşamına Yansımaları-Panel

Sendikacılığına Bakış Açısı ve ILO Normları

Nihat Alayoğlu

Toker Dereli

Özlem Işı̆̆ıç̧ok

İbrahim Yumuşak,

Mahmut Bilen,

Yüksel Bayraktar,

Armağan Türk

Ali Sayın

Abdurrahman

Benli, Özgür

Topkaya

Metin Kutal

Ali Kemal Sayın,

Ahmet Gündoğdu,

Bircan Aky1ldız,

Bülent Pirler,

Nejdet Okcan,

Semih Temiz

Adnan

Mahiroğulları

Grevsiz Toplu Pazarlık Hakkı ve Aidat Bağımlılığı Kıskacında

Memur Sendikaları

Sayım Yorgun

Metin Kutal 
1980'den itibaren ILO'nun ağır eleştirilerine maruz kalan (Dereli, 2008: 2015; Kutal, 2012: 111). Türkiye'de 1982 ve 2012 döneminde yapılmış olan 58 çalışma bulunmaktadır. Bu çalışmalardan doğrudan "ILO” anahtar kelimesini içeren 13, "ILO ve çocuk çalışma" anahtar kelimelerinin ikisini de içeren 4 çalışma, "ILO ve Sendika" anahtar kelimelerini birlikte içeren 4 çalışma bulunmaktadır. Bu alt dönemde "sendika" anahtar kelimesini içeren 22 çalışma bulunduğu görülmektedir. "Ücret”" konusunda 9, "çocuk ve çalışma" konusunda 4, "yaş" ve "ayrımcılık" konularında ise birer çalışma bulunmaktadir.

Özdemir (1998) çalışmasında "zorunlu” çalışma kavramı ele alınmaktadır. İnsanların, dünyanın her yerinde emeğinden ırksal, sosyal, siyasal, dinsel ve özellikle ekonomik motiflerden hareket ederek kullanmış, insan onur ve haysiyetiyle bağdaşmayacak kötü koşullarda çalıştırmış olduğunun anlatıldığı çalışmada kişilerin insan olmaktan dolayı haklara sahip oldukları vurgulanmaktadır. İnsanlara ve insan haklarına uluslararası düzeyde önem veren modern çağa girildiğinde, "geleneksel zorunlu çalışma” tipleri ortadan kalkmış, yerini "modern zorunlu çalışma" tipleri almıştır. Günümüzde, "borç esareti" (insanların, borçlandığı kişilere hayatları boyunca sürebilecek bir şekilde hizmet yükümlülüğü ile bağlanması) ve "insanların, özellikle çocukların silah zoruyla kaçırılarak çalıştırılmaları" en açık zorunlu çalışma örnekleridir. ILO tarafından 1930 yılında çıkarılan Zorunlu Çalışma Sözleşmesi ve bu sözleşmeyi tamamlayıcı özelliğe sahip olan 1957 tarihli 105 sayılı Zorunlu Çalışmanın Kaldırılmasına Dair Sözleşme zorunlu çalışma ve angaryayı kesinlikle yasaklamaktadır (Özdemir, 1998: 182). İnsanlık onuruna aykırı bir uygulama olan zorunlu çalışma, uluslararası insan hakların belgelerinin hemen hepsinde yasaklanmaktadır.

Temel amaçları Insan haklarını savunmak olan çeşitli kuruluşlar, zorunlu çalışma, angarya ve köleliği yasaklayıcı hükümlerin de yer aldiğı birçok uluslararası belge hazırlayıp ilan etmişlerdir. Bunlardan bazıları şunlardır: Kölelik Sözleşmesi (1926) (Milletler Cemiyeti); Insan Haklarl Evrensel Bildirgesi (1948), Kölelik Sözleşmesi (1955), Köleliğin, Köle Ticaretinin ve Köleliğe Benzer Kurum ve Uygulamaların Kaldırılmasına Dair Ek Sözleşme (1957). Kişisel ve Siyasal Haklar Sözleşmesi (1966), Ekonomik, Sosyal ve Kültürel Haklar Uluslararası Sözleşmesi (1966) (Birleşmiş Milletler); Avrupa 
Insan Hakları Sözleşmesi (1950), Sosyal Şartı (1961) (Avrupa Konseyi); Zorunlu Çalışma Sözleşmesi (1930), Zorunlu Çalışmanın Kaldırlmasina Dair (Dolayl Zorunluluk) Tavsiye Kararı (1930), Zorunlu Çalışmanın Kaldırılmasina Dair Sözleşme (1957) (Uluslararası Çalışma Örgütü) (Özdemir, 1998: 184).

Selamoğlu, endüstri ilişkileriyle ilgili uluslararası alanda oluşan genel eğilimleri ve Türkiye'nin bunlar karşısındaki durumunu değerlendirmiş, insan hakları ve temel özgürlükleri ayrım gözetmeksizin herkes için vazgeçilmez olduğu çağımızın önemli ilkelerinden biri olarak vurgulamıştır. Günümüzde insan varlığının ayrılmaz parçası olan bu haklara yıllar süren uzun mücadeleler sonucu ulaşılmıştır (Selamoğlu, 1998: 116).

Bu mücadeleler ve zorunlu çalışmanın ve angaryanın yasaklanmasının yanı sıra çalışanlar bakımından iş güvencesinin varlığı da son derece önemlidir. İş güvencesi gerçekten çok önemli bir olgu. Çalışanlar için bir temel taşı. İş güvencesi ile amaçlanan işçinin keyfi dediğimiz, haksız dediğimiz fesihlere karşı korunması. Taşkent'e göre; iş güvencesinin sağlanmasında amaç işçinin işini koruyabilmesidir, işini kaybettikten sonra tazminat ödenmesi iş güvencesinin ilk hedefi değildir (Taşkent, 2003: 155). Haksız işten çıkarmalara karşı işçiyi koruyan gerçek önlem; iş güvencesi sistemidir. İş güvencesi kavramı ilk defa 1917 yılında Meksika Anayasasında yer almış ve sonra 1931 yılında Kanuna aktarılmıştır. Daha sonra Avrupa'da yavaş yavaş ülkelerin mevzuatlarında iş güvencesi sistemineyer verilmeye başlanmıştır. Ancak oralarda işçi sendikalarının etkin, güçlü olması sonucunda, toplu iş sözleşmelerinde bu tür önlemlere yer verilmektedir. Örneğin, işsizlik sigortası uygulaması, önce sendikaların toplu pazarlık sonucu yarattığı bir sistem olarak ortaya çıkmış ardından devlet kanun olarak genelleştirmek durumunda kalmıştır (Taşkent, 2003: 156).

Çalışma hayatı ile ilgili olarak çocukların işgücü piyasalarında yer alması çözülmesi gereken önemli sorunlardan biridir. Çocuğun çalışması, hemen bütün ülkelerde yaşanmakta olan evrensel bir olgudur ve önemli bir sosyal problem olmaya devam etmektedir. Ulusal yasaların ve uluslararası standartların varlığına rağmen milyonlarca çocuğun günümüzde de tüm dünyada çoğunlukla sağlıklı gelişim şartlarına aykırı şekilde çalıştırıldı̆̆ izlenmektedir. Bölgelerin gelişmişliğine bağlı olarak dünya genelinde ortalama beş ila üç çocuktan biri ekonomik olarak faaldir ve bu çocukların büyük kısmı, gelişmekte olan ülkelerde yaşamaktadırlar (Pirler, 2003: 165). Aslantepe (2003: 227-230) 
ILO'nun kuruluşu ve kabul edilen sözleşmeler ile ilgili bilgi vermekte, çocuk istihdamı ile ilgili sözleşmeleri kronolojik olarak sıralamaktadır. ILO, 1999 yılı Konferansında 182 sayılı "Çok Kötü Biçimlerdeki Çocuk İşçiliğinin Yasaklanması ve Ortadan Kaldırılmasına İlişkin Acil Eylem Sözleşmesini” ve 190 sayıl1 “Tavsiye Kararı”nı kabul etmiştir (Pirler, 2003: 165). Türkiye’de 182 sayılı sözleşme 3 Şubat 2001 tarihinde Resmi Gazete'de yayınlanarak yürürlüğe girmiştir (Aslantepe, 2003: 229).

$\mathrm{Bu}$ dönemdeki ILO ile ilgi çalışmalarından biri de Sayın tarafından yazılmış olan ve özel istihdam bürolarını emek piyasalarını düzenleyen uluslararası normlar bağlamında çalışmadır. Emek piyasalarını düzenleyen uluslararası normlar, iş imkânlarının daha yaygın kitlelere ulaşmasını sağlamayı ve niteliklere uygun arz ve talebi bir araya getirmeyi amaçlamaktadır. Uluslararası normlar bunu yaparken, işletmelerin gereksinmeleri ile işçilerin korunması arasında bir denge sağlamaya çalışmaktadır (Sayın, 2004: 53). Sayın'ın diğer çalışması da istihdam hizmetlerinin sunumu ile ilgili tarihi ve sosyal koşullara ve denge arayışı ile istihdam alanında olumsuzlukları giderme çabasının ILO normlarındaki tarihi süreçte de görüldüğünü vurgulamaktadır (Sayın, 2009: 269-280).

Türkiye'de turizm sektöründe ILO normlarının uygulanabilirliğini araştıran bir projeye dayalı olarak yazılmış olan çalışmada Dinçer vd. Türkiye emek piyasalarında yaşanan tüm sorunların turizm sektöründe de görüldüğünü belirterek konunun araştırma aşamasında Çalışma ve Sosyal Güvenlik Bakanlığı, Turizm Bakanlığı, ILO Türkiye temsilciliğine anket uygulamışlardır (Dinçer vd. 2005: 335-358). Turizm sektörünün çalışma yaşamını etkileyen üç unsur bulunmaktadır: esnek çalışma, mevsimlik istihdam ve iş görenlerin çok yönlü beceriye sahip olmaları. Otel, yiyecekiçecek, ikram ve turizm sektöründe çalışanlar ile işverenler arasında oluşturulması gereken sosyal diyaloga daha çok gereksinim olduğu göze çarpmaktadır. Bu sektörde, sendikaya üye olan iş görenlerin sayısı diğer sektörlere göre daha düşüktür (Dinçer vd. 2005: 340). Türk turizm istihdam yapısında iş görenlerin genç bir nüfus sergilemeleri, kıdem düzeylerinin düşük bulunması, sosyal hakların yetersizliği işgücünü olumsuz etkilediği sonuçlarına ulaşılmıştır (Dinçer vd. 2005: 342).

Erdem, (2008) çalışmasında ILO'nun Türkiye'ye yapmış olduğu ilk teknik yardım faaliyetleri içerisinde Yakın ve Orta Doğu Çalışma Enstitüsü’nün (YODÇE) kuruluşu incelenmektedir. 
1999 y1lında ILO Genel Müdürü Juan Somavia tarafindan, dünya kamuoyuna takdim edilmiş olan "İnsana Yakışır İş", Işı̆̆ıçok (2009) tarafından ele alınmaktadır. Literatürde "düzgün iş", "uygun iş", "saygın iş", "insan onuruna yakışır iş" kavramlarıyla da nitelenen "insana yakışır iş" ILO tarafından "çalışma yaşamında bireylerin temel haklarının korunduğu, yeterli bir gelir ve sosyal koruma sağlayan üretken bir iş" olarak tanımlanmaktadır. İnsana yakışır iş için; iş firsatları, çalışma özgürlüğü, üretken iş, işte adil ve eşit davranış görme, işte güvenlik ve saygınlık olmak üzere 6 boyut söz konusudur (Işığıçok, 2009: 310).

Benli ve Topkaya (2010) çalışmalarında 1980 öncesi planlı ekonomik dönemde üç demir yemek tabağı olarak da bilinen ve çalışanlara iş garantisi, beşikten mezara sosyal güvenlik ve devletin çalışanı sürekli himayesini içeren düzenlemelerinin, yerlerini piyasa ekonomisi düzenlemelerine bırakmakta olduğunu ve 1980'den sonra bu durumun değiştiğini anlatmaktadırlar. Çin Halk Cumhuriyeti (Çin) endüstri ilişkileri 1980 sonrası dönemde, çalışanların ve ILO'nun beklentilerine yönelik olarak şekillenmekte ve çağdaş düzeye gelmesi yönünde çaba sarf edilmektedir (Benli ve Topkaya, 2010: 214).

Mahiroğulları çalışmasında, 1965'ten 12 Eylül 2010 Referandumu'na yasa koyucunun memur sendikacılığına bakış açısı irdelenmiş; memur sendikacılığıyla ilgili yasaların ILO normlarıyla çelişip çelişmediği ele alınmıştır (Mahiroğulları, 2011: 61-87).

$\mathrm{Bu}$ alt dönemde düzenlenen Anayasa Değişikliği ve Çalışma Yaşamına Yansımaları konulu Sosyal Siyaset Konferansları açılış konuşmasında Gökçen (2011: 476) Çalışma Ekonomisi ve Endüstri İlişkileri bölümünün İktisat Fakültesinin kurulmasına temel olan eden bir bölümü olduğunu vurgulamıştır. Murat, (2011) tarafindan konferanslar hakkında genel bilgiler verildikten sonra Türkiye'de çalışma hayatı ile ilgili temel gelişmeler hakkında bilgiler verilmektedir. Aynı konferans kapsamında Kutal (2011) Anayasa değişikliği ile ilgili olarak yetersiz alanların/düzenlemelerin neler olduğunun ortaya konulmasından çok nasıl telafi edilmesi, neler eklenmesi gerektiğinin ortaya konulmasının önemi vurgulayarak bu konuda mevcut durumu ve yapılması gerekenleri ortaya koymuştur. 2011 yılında düzenlenen Anayasa Değişikliği ve Çalışma Yaşamına Yansımaları paneli kapsamında da Ali Kemal Sayın, Ahmet Gündoğdu, Bircan Akyıldız, Bülent Pirler, Nejdet Okcan, Semih Temiz panelist olarak konu ile ilgili görüşlerini paylaşmışlardır (Gündoğdu vd., 2011: 497-530). 
26.12.2011 tarihinde Toplu İş Hukukunda Yeni Yasal Düzenlemeler konulu 61. Sosyal Siyaset Konferansı'nda açılış konferansında 2821 ve 2822 sayılı yasaların yerini alacak olan ve Çalışma ve Sosyal Güvenlik Bakanlığı tarafindan hazırlanan Toplu İş İlişkileri kanunun bilimsel yönden incelenmesini amaçlandığı ifade edilmektedir (Kutal, 2012: 105-152).

$\mathrm{Bu}$ alt dönem genel olarak değerlendirildiğinde Tablo 12 kapsamında yer alan eserlerin çalışma yaşamına ilişkin konulara geniş bir perspektifle yaklaştığını, gündemdeki konular ilgili bilimsel yaklaşımlarla yol gösterici ve yapıcı katkıların söz konusu olduğu belirtilebilir. Doğrudan ILO ile ilgili çalışmaların ILO düzenlemeleri, sözleşme ve tavsiye kararlarının ulusal mevzuata yansımaları, memur sendikacılığı ya da sektörel gelişmeler gibi

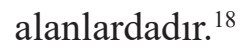

\section{Sosyal Siyaset Konferansları Dergisi’nde 2015 - 2019 Yılları Arasında Yer Alan ILO Konulu Çalışmalar}

Bu alt dönemde 1929 Büyük Bunalımı sonrasındaki en ciddi küresel kriz olan 2008 krizinin etkilerinin devam ettiği belirtilebilir. Krizin olumsuz etkileri dünya genelinde de tam olarak ortadan kaldırılamamıştır (Selamoğlu, 2017: 29).

OECD ülkeleri için 2014 verilerine göre Türkiye uzun çalışma saatleri bakımından birinci sırada yer almaktadır. Kayıt dışı istihdam, ayrımcılık, iş kazaları, iş sağlığı ve güvenliği mevzuatının yeterince uygulanamaması gibi sorunların yanı sıra toplumsal cinsiyet eşitliği çerçevesinde kadın istihdamını arttırmaya yönelik çabaların yetersizliği, karar alma pozisyonundaki kadınların oranında bir artış gözlenmezken (Karataş - Başçıllar ve Taşçi, 2019: 208) kadına şiddetin artması gibi dönem içinde yaşanan genel sorunlar bulunmaktadır.

15 Temmuz 2016 Darbe girişimi bu alt dönemin en önemli olayıdır. Yine 2019 yılı itibariyle sayıları 4 milyonu aşan Geçici Koruma Kapsamındaki Suriyeli Türkiye'de ekonomik, sosyal, kültürel ve demografik açılardan etkide bulunan bir durumdur.

18 Tablo kapsamında yer alan çalışmalardan doğrudan ILO ile ilgili olanlar açıklanmıştır. 
Tablo 14

Sosyal Siyaset Konferanslarl Dergisi'nde 2015 - 2019 Yilları Arasinda Yer Alan ILO Konulu Çalışmalar

\begin{tabular}{|c|c|c|}
\hline Yll & Makale Başlığı & Yazar \\
\hline \multirow{6}{*}{2015} & Sendika İçi Demokrasi ve Sendika İçi Kadın Örgütlenmesi & Betül Urhan \\
\hline & $\begin{array}{l}\text { 5018 Sayılı Kanun'un Temel Felsefesiyle Çelişki: Gayr-1 } \\
\text { Siyasi Sendikacılıktan Partili Sendikacılığa Yöneliş (1947- } \\
\text { 1960) }\end{array}$ & Adnan Mahiroğulları \\
\hline & $\begin{array}{l}\text { Bireysel Sendika Özgürlüğünün Türkiye’de } 2821 \text { ve } 6356 \\
\text { Say1lı Yasalarda Sendikal Nedenle İş Sözleşmesinin Feshi } \\
\text { Bağlamında Güvencesi }\end{array}$ & M. Engin Sanal \\
\hline & The Benefits of Freedom of Association for Development & Toker Dereli \\
\hline & $\begin{array}{l}\text { Türkiye'de Olumsuz Sendikal Algının İçsel ve Dışsal Ned- } \\
\text { enleri }\end{array}$ & Banu Uçkan Hekimler \\
\hline & Uluslararası İnsan Hakları Hukukunda Toplu Eylem Hakkı & $\begin{array}{l}\text { Pir Ali Kaya, Ceyhun } \\
\text { Güler }\end{array}$ \\
\hline 2016 & $\begin{array}{l}\text { Askeri Darbeler Döneminden Sivil Demokrasi Dönemine } \\
\text { Brezilya'da Sendikacılık }\end{array}$ & Adnan Mahiroğulları \\
\hline 2019 & $\begin{array}{l}\text { Bir Sosyal Politika Analizi: Türkiye’de Asgari Ücret } \\
\text { Uygulamas1 }\end{array}$ & $\begin{array}{l}\text { Mehmet Öçal, Âdem } \\
\text { Korkmaz }\end{array}$ \\
\hline
\end{tabular}

8 çalışmanın olduğu bu alt dönemde yapılmış olan çalışmalardan doğrudan "ILO" anahtar kelimesini içeren 2 çalışmaya karşılık "sendika" konulu 5 çalışma bulunmaktadır. "Ücret” konulu çalışma sayısı ise 1'dir.

Dereli (2017) çalışmasında Türkiye'deki örgütlenme özgürlügü ve endüstri ilişkileri aşamaları dönemler halinde verilmekte, Türkiye'nin endüstri ilişkileri mevzuatının değiştirilmesi ile ilgili çeşitli endişe sorunlara rağmen ILO tarafından önerilen konuların yüksek öncelikli olarak ele alınması gerektiği vurgulanmaktadır.

Kaya ve Güler (2015) çalışmalarında düşünce ve ifade özgürlüğü kapsamında değerlendirilen temel bir insan hakkı olarak toplu eylem hakkını hukuki dayanakları, toplu eylem hakkının niteliği ve bu hakkın meşru sayılması için aranan şartlar bağlamında tartışmaktadırlar.

Akademik yayınların güncel gelişmeleri takip etmesinin eş zamanlı olmadığı göz önünde bulundurulursa derginin konu ile ilgili bu alt döneminin daha ayrıntılı analizinin yapılabilmesi için en azından 2019 yılı tüm dergi sayılarının yayınlanmış olması gerekmektedir. 


\section{Sonuç}

Türkiye'de akademik bilgiyi üretme ve yayma anlamında önemli bir rol üstlenen ve 1948 yılından günümüze kadar yayın hayatını sürdüren "Sosyal Siyaset Konferansları Dergisi”, emek-sermaye ilişkileri, işsizlik, yoksulluk, sosyal yardımlar, sosyal hizmetler ve dezavantajlı gruplara yönelik politikalar gibi sosyal politikanın konularını kapsayan bir dergidir. İlk olarak 1948 yılında "İçtimai Siyaset Konferansları" adıyla basılmaya başlanmıştır. Prof. Kessler tarafindan hazırlanan "Sosyal Siyaset Konferansları”, Altan'1n (2007) da belirttiği üzere Türkiye' deki ilk sosyal politika külliyatını oluşturmaktadır.

Sosyal Siyaset Konferansları Dergisi'nde yer alan ILO ile ilgili makalelerin nitel analiz yöntemleriyle incelendiği bu çalışmada öncelikle genel olarak derginin bibliyometrik verileri incelenmiştir. Dergi kapsamında internetten elde edilen 854 dosya bulunmaktadır. Bu dosyalardan kapak sayfası ve editör notu gibi dosyalar dışarıda bırakıldığında 830 metin dosyasına ulaşılmıştır.

Çalışmada başlığında doğrudan ILO bulunan 30 çalışma bulunmaktadır. Bu sayı toplam çalışma sayısının \%3,6'sıdır. Alper ve Kaya (1995: 2)'da ifade edilen ILO'yu doğrudan ele alan çalışmaların az olduğu görüşü ele alınan dergi kapsamında da tekrarlanabilir. Hatta çalışmaların görülme ve indirilme sayılarının verildiği tablolar da dikkate alındığında ILO konulu çalışmalar gelir dağılımı ya da göç ile ilgili çalışmalardan daha az sayıda görüntülenme ve indirilme sayılarına sahiptir.

Türkiye ILO ilişkilerinin 1932-1946, 1946-1959, 160-1980 ve 1980-2015 olarak dönemleştirildiğinden hareketle dergideki çalışmalar da bu dönemlere uyumlu olarak tasnif edilmişstir.

$\mathrm{Bu}$ çalışmanın temel hipotezi genel olarak uzun dönemli akademik yayınların ilgili olduğu dönemin sosyal, siyasal ve ekonomik gelişmelerinin yansımasını okuyuculara sunabilmesinin bilimsel ve akademik gelişme için önemli olduğudur. Bu düşünceden hareketle ILO'nun dergiye nasıl yansıdığının incelenmesi sonucunda dergiye gelen çalışmaların yoğun olmadığ 1 söylenebilir. Ancak bu noktada editör yazılarının da hatırlatılması yerinde olacaktır. İnceleme kapsamında yer alan editör yazılarında dergiye makale gönderme çağrısı yapılırken hep "dergiyi yaşatma" vurgusu yapılmıştır. Bu bağlamda belli bir konu ile ilgili çalışmaları incelemekten öte akademik yayınlara çalışma gönderme, kabul süreçleri, kabul alma, bu 
çalışmaları akademik bilgi paylaşımlarında kullanma ya da akademik atama ve yükseltmelerde kullanma ile ilgili mevcut yapının ayrıntılı ve eleştirel olarak analiz edilmesi gerekir. Mevcut çalışmanın sınırlarının dışında olan ama çalışmaya karar vermedeki temel düşünce ve hipotez yanında zımni olarak içerilmiş olan başka bir düşüncenin varlığı söz konusudur. Bu düşünce de Türkiye'de akademik yayıncılıkta önemli bir yer tutan dergilerle ilgili olarak yapılan çalışmaların çoğalması yolunda bir farklılık oluşturabilmektir. Alan ile ilgili olarak belirtilebilecek 1943 yılından itibaren yayın hayatını sürdüren Ankara Üniversitesi SBF Dergisi, 1948'den beri varlığını sürdüren Sosyal Siyaset Konferansları Dergisi gibi köklü dergiler belli konularda külliyat oluşturmuş olan kıymetli eserlerdir.

Türkiye'nin sosyal politika tarihinin gelişimi ile eş zamanlı büyüyen ve gelişen Sosyal Siyaset Konferansları Dergisinin gelenekten geleceğe sahip olduğu misyonunu koruyarak, gelişip büyüyen, gelenek oluşturan ve bu geleneğin devamını sağlayan ve arkasında önemli bir kolektif gücü barındıran yönleri bulunmaktadır.

Finansal Destek: Yazar bu çalışma için finansal destek almamıştır. 


\section{Kaynakça/References}

Alper, Y. ve Kaya, P. A. (1995). 75. Kuruluş Yıldönümünde Uluslararası Çalışma Örgütü ve Uluslararası Çalışma Standartları, Uludă̆ Üniversitesi İktisadi ve İdari Bilimler Fakültesi. Bursa: Ezgi Kitabevi Yayınları.

Altan, Ö. Z. (2007). Sosyal Politika, Anadolu Üniversitesi Açıköğretim Fakültesi Ya. No. 1744, Açıköğretim Fakültesi Ya. No. 900, Eskişehir.

Arndt, H. (1955). Asgari Ücret, Sosyal Siyaset Konferanslarl Dergisi, 7, 33-40.

Aslantepe, G. (2003). Çocuk istihdamı konusunda ILO Normları ve ILO-Türkiye Cumhuriyeti ilişkileri. Sosyal Siyaset Konferansları Dergisi, 45, 227-230.

Benli, A. ve Topkaya, Ö. (2010). Çin endüstri ilişkileri ve 1980 sonrası dönemde yaşanan dönüşümler. Sosyal Siyaset Konferansları Dergisi, 59, 179-216.

Boratav, K. (1988). Türkiye iktisat tarihi 1908-1985. İstanbul: Gerçek Yayınevi.

Boratav, K. (1997). İktisat Tarihi 1981-1994, Türkiye Tarihi 5, Bugünkü Türkiye 19801995, Tanör, B.- Boratav, K. ve Akşin, S. içinde, s.s. 161-213, Cem Yayınevi: İstanbul.

Boratav, K. (2006). Sosyal bilimler veri tabanı çalışmalarında tarihsel perspektif. Ankara: Sosyal Bilimlerde Süreli Yayıncılık Kurultayı.

Buğra, A. (2010). Kapitalizm, yoksulluk ve Türkiye'de sosyal politika. İstanbul: İletişim Yayınları.

Cam, E. (2008). Uluslararası çalışma örgütü’nün Türkiye’ye ilk teknik yardım faaliyetleri çerçevesinde yakın ve Orta Doğu çalışma enstitüsü’nün kuruluşu ve İstanbul dönemi faaliyetleri (1955 - 1972). Sosyal Siyaset Konferanslarl Dergisi, 55, 79-126.

Çatı, K. ve Öcel, Y. (2018). Türkiye'de pazarlama ile ilgili yayınlanan makalelerin bibliyometrik incelenmesi. İşletme Araştırmaları Dergisi (Journal of Business Research), 10(3), 508-519.

Çetinkaya-Bozkurt, Ö. ve Çetin, A. (2016), Girişimcilik ve Kalkınma Dergisi’nin bibliyometrik analizi. Girişimcilik ve Kalkınma Dergisi, 11(2), 229-263. http:// acikerisim.lib.comu.edu.tr:8080/xmlui/handle/COMU/1668, (12.05.2019).

Costa, L. (1954). ILO’nun tekstil işçilerine sağladığı faydalar, (Çev. Reşit Erkul). Sosyal Siyaset Konferansları Dergisi, 6, 39-46.

Dereli, T. (2003). Önsöz. Sosyal Siyaset Konferanslarl Dergisi, 45, 1.

Dereli, T. (2008). Uluslararası Çalışma Örgütü (ILO) normları açısından Türkiye'de sendika özgürlükleri ve yeni yasa taslağının değerlendirilmesi. Sosyal Siyaset Konferanslarl Dergisi, 54, 215-235.

Dereli, T. (2017). The benefits of freedom of association for development. Sosyal Siyaset Konferanslarl Dergisi, 68, 187-220.

Dinçer, M. vd. (2005). Turizm sektöründe uluslararası çalışma örgütü normlarının önemi ve bu normların Çalışma ve Sosyal Güvenlik Bakanlığı, UÇO Türkiye Temsilciliği ve Turizm Bakanlığı Tarafından değerlendirilmesine yönelik bir araştırma. Sosyal Siyaset Konferanslart Dergisi, 49, 335-358. 
Doğan, G. (2018). BBY 252 Araştırma Yöntemleri (2018 Bahar) Açık Ders Notları, http://www.acikders.net/course/view.php?id=253, (04.07.2019).

Ekin, N. (1986). Türkiye'de endüstri ilişkilerinin gelişimi ve 1936 İş Kanunu. Sosyal Siyaset Konferanslarl Dergisi, 35-36, 33-51.

Ersoy, B. (1955). Türk sendikacılığının inkişafına mani olan bazı sebepler. Sosyal Siyaset Konferansları Dergisi, 7, 41-50.

Fındıkoğlu, Z. F. (1952). İzmir'de işçi sendikaları hakkında sosyolojik bazı müşahedeler. Sosyal Siyaset Konferansları Dergisi, 5, 3-23.

Furgaç, H. (1955). Hayat pahalılığı ve ücretlerin tayini. Sosyal Siyaset Konferanslart Dergisi, 7, 51-60.

Gökçen, A. ve Murat, S. (2011). Anayasa değişikliği ve çalışma yaşamına yansımalarıaçılış konuşmaları, anayasa değişikliği ve çalışma yaşamına yansımaları-açılış konuşmaları, Sosyal Siyaset Konferansları Dergisi 60, 475-482. http://dergipark.org. tr/iusskd/issue/923/10462, (13.08.2019).

Güçlü, S. ve Bilen, M. (1995). 1980 sonrası dönemde gelir dağılımında meydana gelen değişmeler. Yeni Türkiye Dergisi, 6, 160-171.

Gülmez, M. (2013). Uluslararası Sözleşmelerde Sosyal ve Sendikal Haklar ve Türkiye ’nin Durumu, Sendikacılık Akademisi Ders Notları 2, TÜRK-İŞ (Türkiye İşçi Sendikaları Konfederasyonu) Yayınları, Ankara, http://www.turkis.org.tr/dosya/7FUC1XaeWA6B. pdf (11.09.2019).

Gülmez, M. (2019). İçimdeki ukde: İş hukuku ve sosyal politika öğretilerinin sosyal insan haklarıyla imtihanı (1938-2015). Ankara: Siyasal Kitabevi.

Gündoğdu, A. ve ark. (2011). Anayasa değişikliği ve çalışma yaşamına yansımalarıpanel, Sosyal Siyaset Konferanslar Dergisi, 60, 497-530.

Gürtan, K. (1961). Türkiye'de ücret istatistikleri ve ücret tahavvülleri. Sosyal Siyaset Konferanslarl Dergisi, 12, 17-30.

Güzeller, C. O. ve Çeliker, N. (2017). Geçmişten günümüze gastronomi bilimi: bibliyometrik bir analiz. Journal of Tourism and Gastronomy Studies, 5, 88-102.

Isaac, A. (1949). Ücret sistemleri. Sosyal Siyaset Konferansları Dergisi, 2, 49-64.

Işığıçok, Ö. (2009). Küreselleşme sürecinde insana yakışır iş. Sosyal Siyaset Konferansları Dergisi, 56, 307-331.

Işık, R. (1968). Milletlerarası çalışma sözleşmelerinin Türk mevzuatına tesiri. Sosyal Siyaset Konferanslarl Dergisi, 19, 167-174.

Jain, K. (1961). Yakın ve Ortadoğu'daki teknik yardım faaliyetleri açısından milletlerarası çalışma teşkilatı ve az gelişmiş memleketler, (Çev. Dereli, T.). Sosyal Siyaset Konferanslarl Dergisi, 12, 99-113.

Karataş, K., Başçıllar, M. ve Taşçi, A. (2019). Türkiye-Avrupa Birliği ilişkilerinin etkileri bağlamında Türkiye sosyal politikasının değişimi. CBÜ Sosyal Bilimler Dergisi, 17(2), 196-218. 
Kaya, P. A. ve Güler, C. (2015). Uluslararası insan hakları hukukunda toplu eylem hakkı. Sosyal Siyaset Konferanslarl Dergisi, 68, 105-126.

Kutal, M.(1970). Uluslararası çalışma teşkilatının yasama faaliyeti ve Türkiye Cumhuriyetinin durumu (1919-1969). Sosyal Siyaset Konferanslarl Dergisi, 21, 169-198.

Kutal, M. (1995). Endüstri ilişkileri açısından 1992 yılının başlıca özellikleri ve gelişmeleri. Sosyal Siyaset Konferansları Dergisi, 40, 11-16.

Kutal, M. (2008). Uluslararası Çalışma Örgütü (ILO) normları açısından Türkiye'de sendika özgürlükleri ve yeni yasa taslağının değerlendirilmesi. Sosyal Siyaset Konferanslart Dergisi, 54, 215-235.

Kutal, M. (2011). Anayasa değişikliği ve çalışma yaşamına yansımaları açılış konferansı. Sosyal Siyaset Konferanslarn Dergisi, 60, 483-496.

Kutal, M. (2012). 61. Sosyal Siyaset Konferanslar1, Sosyal Siyaset Konferansları Dergisi, 62-63, 105-152.

Kutal, M. (2012). Toplu İş Hukukunda Yeni Yasal Düzenlemeler, 61. Sosyal Siyaset Konferansları Açılış Konferansları. Sosyal Siyaset Konferansları Dergisi, 62-63, 105152.

Mahiroğulları, A. (2012). 1965'ten 12 Eylül 2010 halk oylamasına yasakoyucunun memur sendikacılığına bakış açısı ve ILO normları. Sosyal Siyaset Konferansları Dergisi, 60, 61-87.

Man, F. (2011). Türkiye'de örgütlü emek ve devlet söylemi: Tekel eylemleri örneği. Sosyal Siyaset Konferanslarl Dergisi, 61, 63-79.

Nalbandoğlu, R. (1950). Ücretler ve fiyatlar. Sosyal Siyaset Konferanslarl Dergisi, 3, $65-83$.

Önsal, N. (2010). Endüstri ilişkileri notları. TÜRK-İ̧̧ Türkiye İşçi Sendikaları Konfederasyonu. Ankara: TÜRK-İŞ Türkiye İşçi Sendikaları Konfederasyonu Yayını.

Özdemir, S. (1998). Türkiye'de “Zorunlu çalışma"” uygulamaları. Sosyal Siyaset Konferanslarl Dergisi, 41-42, 181-214.

Özdemir, S. (2011b). Editör Yazıs1. Sosyal Siyaset Konferansları Dergisi, 61, iii-v.

Pirler, B. (2003). TİSK genel sekreteri Bülent Pirler'in Dünyada ve Türkiye'de çocuk işgücüne ilişkin görüş ve önerileridir. Sosyal Siyaset Konferansları Dergisi, 46, 165174.

Sarığlu, H. İ. (2004). Editörden. Sosyal Siyaset Konferanslarl Dergisi, S. 47, i-iii.

Sarığlu, H. İ. (2003). Editörden. Sosyal Siyaset Konferansları Dergisi, S.44, i-iv.

Sayın, A. K. (2004). Emek piyasalarını düzenleyen uluslararası normlar. Sosyal Siyaset Konferanslart Dergisi, 48, 53-96.

Sayın, A. K. (2009). Özel istihdam büroları: Türkiye örneği. Sosyal Siyaset Konferanslarl Dergisi, 57, 269-280.

Saymen, F. H. (1948). Türk İşçi Sendikalarının karakterleri. Sosyal Siyaset Konferansları Dergisi, 1, 82-105. 
Selamoğlu, A. (1998). Endüstri ilişkileri boyutlarıyla uluslararası andlaşmalar ve Türkiye. Sosyal Siyaset Konferansları Dergisi, 41-42, 115-138.

Selamoğlu, A. (2017). 2008 Krizi ve Avrupa Birliği yeni yönetişim kıskacında endüstri ilişkileri. Sosyal Siyaset Konferansları Dergisi, 68, 25-61.

Soyak, A. (1999). Planlı dönemde sanayileşme. 75 Yılda Çarklardan Çiplere, 167-181. İstanbul: Türkiye Tarih Vakfi.

Saymen, F. H. (1961). Milletler arası çalışma teşkilatının teşrii faaliyeti ve Türkiye. Sosyal Siyaset Konferanslar Dergisi, 12, 114-132.

Söngütay, B. (1952). Milletlerarası çalışma teşkilatı. Sosyal Siyaset Konferansları Dergisi, 5, 24-32.

Sönmez, M. (2001). Gelir uçurumu, Türkiye'de gelirin adaletsiz bölüşümü. İstanbul: OM Yayınevi.

Taşkent, S. (2003). Türk iş mevzuatında iş güvencesi sorunu ve hazırlanan yasa tasarısının esasları. Sosyal Siyaset Konferansları Dergisi, 45, 155-176.

Timur, T. (2006). Türkiye'de sosyal bilimler alanındaki bilimsel süreli yayınlarla ilgili sorunlar, 16-21. Ankara: Sosyal Bilimlerde Süreli Yayıncılık Kurultayı.

Tonta, Y. (2009). Diğer araştırma yöntemleri: Bibliyometri, atıf analizi, yöneylem araştırması. http://yunus.hacettepe.edu.tr/ tonta/courses/spring2009/bby208/, (21.08.2019).

Tuna, O. (1950). İşçi sendikalarının mahiyet ve vazifeleri. Sosyal Siyaset Konferansları Dergisi, 3, 131-141.

Tuna, O. (1951). Bugünkü Sovyet sendikalizminin nazari ve tatbiki esasları. Sosyal Siyaset Konferanslart Dergisi, 4, 78-92.

Tuna, O. (1954). Memleketimizde sendikacılık hareketlerinin gelişmesi ve işçilerimizin sendikalaşma meselesi. Sosyal Siyaset Konferansları Dergisi, 6, 61-68.

Tuna, O. (1955). Sendikacılık ve siyaset. Sosyal Siyaset Konferansları Dergisi, 7, 105121.

Tuna, O. (1956). Memleketimizde sendikaların üzerinde durdukları meseleler. Sosyal Siyaset Konferanslar Dergisi, 8, 103-119.

Tuna, O. (1969). Sosyal Siyaset Konferanslarının yirminci y1lı. Sosyal Siyaset Konferansları Dergisi, 20, 1-8.

Tuna, O. (1978). Çalışma organizasyonlarının doğuşu. Sosyal Siyaset Konferansları Dergisi, 29, 1-30.

Yılmazel, Ö. (2019). Anadolu Üniversitesi İktisadi ve İdari Bilimler Fakültesi Dergisi’nin bibliyometrik analizi. Anadolu Üniversitesi İktisadi ve İdari Bilimler Fakültesi Dergisi, 20(1), 1-13.

Zadil, E. (1955). İşçi ve sendikacıların eğitimi. Sosyal Siyaset Konferansları Dergisi, 7, $122-146$.

Zaim, S. (1956). Türkiye mensucat sanayiinde ücretler. Sosyal Siyaset Konferanslart Dergisi, 8, 25-41. 
Zaim, S. (2007). İ.Ü. İktisat Fakültesi Çalışma Ekonomisi ve Endüstri İlişkileri Bölümünün tarihçesi ve gelişimi. Sosyal Siyaset Konferansları Dergisi, 52, 321-336. https:/cabim.ulakbim.gov.tr/bibliyometrik-analiz/bibliyometrik-analiz-sikca-sorulansorular/, (07.10.2019).

http://disk.org.tr/2016/05/turkiyenin-uluslararasi-calisma-orgutu-karnesi/, (21.08.2019). http://www.calismatoplum.org/, (05.09.2019).

http://www.nedirnedemek.com/beveridge-raporu-nedir-beveridge-raporu-ne-demek, (Erişim tarihi: 19.02.2014).

https://dergipark.org.tr/tr/pub/ausbf/archive, (05.09.2019).

https://www.ilo.org/wcmsp5/groups/public/---europe/---ro-geneva/---iloankara/ documents/genericdocument/wcms_645630.pdf, (21.08.2019). 


\section{Ek}

Ek Tablo 1

Yıllara Göre Dergilerde Yer Alan Yayınların Türleri

\begin{tabular}{|c|c|}
\hline Dergi Sayıları ve Yılları & $\begin{array}{l}\text { Dergi Kapsamındaki Çalışmaların Yer Aldığı } \\
\text { Dergi Kategorileri }\end{array}$ \\
\hline Say1 1 ve Say1 44 arasinda (1948-2002) & Makaleler \\
\hline Say1 45 (2003) & Makaleler, Konferanslar, Editör Yazısı ve Diğerleri \\
\hline Say1 $46(2003)$ & Makaleler, Konferanslar \\
\hline Say1 47 (2004) & Makaleler, Konferanslar, Editör Yazısı ve Diğerleri \\
\hline Say1 48 (2004) & Makaleler, Konferanslar \\
\hline Say1 49 ve Say1 50(2005) & $\begin{array}{l}\text { Sosyal Politika, Çalışma İlişkileri, İnsan Kaynakları } \\
\text { Yönetimi, Siyasi ve Sosyal Yapı, Diğer Yayınlar } \\
\text { Hatıra Yazıları }\end{array}$ \\
\hline Say1 51 (2006) & Makaleler, Konferanslar \\
\hline Say1 52 (2007) & Makaleler Konferanslar \\
\hline Say1 53 (2007) & Makaleler, Hatıra Yazıları \\
\hline Say1 54 (2008) & Makaleler, Konferanslar \\
\hline Say1 55 (2008) & Makaleler \\
\hline $\begin{array}{l}\text { Say1 56, Say1 } 57 \text { (2009); Say1 } 58 \text { ve Sayı } \\
59 \text { (2010) }\end{array}$ & Makaleler \\
\hline Say1 60 (2011) & $\begin{array}{l}\text { Makaleler, Dergi Künyesi, Konferanslar, Editör } \\
\text { Yazısı ve Diğerleri }\end{array}$ \\
\hline Say1 61 (2011) & $\begin{array}{l}\text { Dergi Künyesi, Makaleler, Editör Yazısı ve } \\
\text { Diğerleri }\end{array}$ \\
\hline Say1 61-62 (2012); Say1 62-63 & Makaleler, Konferanslar, Editör Yazısı ve Diğerleri \\
\hline Say1 64-65 (2013); Say1 66-67 (2014) & Makaleler, Editör Yazısı ve Diğerleri \\
\hline Sayı 68 (2015) Özel Sayı & $\begin{array}{l}\text { Makaleler, Olay İncelemesi, Hatıra Yazıları, Editör } \\
\text { Yazısı ve Diğerleri }\end{array}$ \\
\hline Say1 69 (2015) Özel Sayı & Makaleler, Editör Yazısı ve Diğerleri \\
\hline Say1 70 (2016) & $\begin{array}{l}\text { Makaleler, Kitap İncelemesi, Hatıra Yazıları, Editör } \\
\text { Yazısı ve Diğerleri }\end{array}$ \\
\hline Say1 71 (2016) & Makaleler, Editör Yazısı ve Diğerleri \\
\hline Say1 72 (2017) Özel Say1 & $\begin{array}{l}\text { Makaleler, Diğer Yayınlar, Hatıra Yazıları, Editör } \\
\text { Yazısı ve Diğerleri }\end{array}$ \\
\hline Sayı 73 (2017) Özel Sayı & $\begin{array}{l}\text { Makaleler, Diğer Yayınlar, Editör Yazısı ve } \\
\text { Diğerleri }\end{array}$ \\
\hline Say1 74 (2018) & Makaleler \\
\hline Say1 75 (2018) & Araştırma Makalesi \\
\hline Say1 76 (2019) & Araştırma Makalesi \\
\hline
\end{tabular}


Ek Tablo 2

20 Yıllık Sosyal Siyaset Konferansları'nın Bu Konferansları Verenler ve Konu Bakımından Dağıllısıı

Orhan Tuna

\section{YIRMI YILLIK SOSYAL SIYASET KONFERANSLARININ, BU KONFERANSLARI VERENLER VE KONU BAKIMINDAN DAĞLLIŞI}

\begin{tabular}{|c|c|c|}
\hline Konferansq̧ının Mesleği & \multicolumn{2}{|c|}{$\neq \quad \%$} \\
\hline Universite Mensublarının verdikleri Konferar & 132 & 67,4 \\
\hline İş̧̧i ve Sendikacılar tarafından verilenler & 16 & 8.1 \\
\hline İsverenler tarafından verilenler & $\mathbf{5}$ & 2.5. \\
\hline Avukatlar (Sendika müşavirleri de dahil) tarafindan verilenler & 7 & 3.6. \\
\hline $\begin{array}{l}\text { Sosyal Mevzuatla IIgili Teşkilât Mensuplarınca verilenler } \\
\text { Milletlerarası Calısma Teskilâtı Mensupları ve Yabancı Uzman- }\end{array}$ & 10 & 5.1 \\
\hline lar tarafindan verilenler & 12 & 6.1 \\
\hline Politikact, Mühendis ve Diğer Uzmanlarca verilenler & 15 & 7.6: \\
\hline TOPLAM & 197 & $100.0^{\circ}$ \\
\hline Konferans Konuları & & $\%$ \\
\hline a) Sendikacilık & 46 & 23.4 \\
\hline b) Utcretler ve Ûcretlerle IIgili Meseleler & 12 & 6.1 \\
\hline c) Iș̣gücü Akımı ve Dönen İş̧̧iler & 21 & 10.7 \\
\hline d) Toplu Pazarlık_Grev ve Lokavt- & 12 & 6.1. \\
\hline e) Sosyal Sigorta ve Sosyal Güvenlik & 10 & 5.1 \\
\hline f) Ișsizlik (İş ve İş̧̧i Bulma Kurumu) & 10 & 5.1 \\
\hline g) Toplulukla İs Uyuşmazlığı & 6 & 3.0 \\
\hline Ziraa & 2 & 1.0 \\
\hline i) Kooperatif̧̧ilik & $\mathbf{2}$ & $1.0^{\mathrm{n}}$ \\
\hline $\begin{array}{l}\text { j) Beşeri Münasebetler, Sevk ve fdare, Iş̧̧i-İsveren Mtina- } \\
\text { sebetleri, Mesleğe Yöneltme ve Meslekí Eğitim }\end{array}$ & & 137 \\
\hline k) Calışma Meseleleri & 9 & $\begin{array}{r}4.8 \\
4.6\end{array}$ \\
\hline Sosyal Siyasetin Teorik ve Pratik Meseleleri & 13 & 6.6 \\
\hline m) Çalışma Meseleleri ile IIIgili Diğer Mevzuat & 5 & 2.5 \\
\hline n) Mesken & 4 & 2.0 \\
\hline o) Milletlerarası Çalışma Teşkilâtı ile fIgili & 4 & 2.0 \\
\hline p) Muhte & 9 & 4.6 \\
\hline r) Ord. Prof. KESSLER için & 5 & 2.5. \\
\hline TOPLAM & 197 & 100.0 \\
\hline
\end{tabular}

Tabloda yer alan konferanslardan 28'i (\% 14,2) İstanbul' da ya da yurtiçindeki işyerlerinde verilmiş, geri kalan konferanslar ise üniversite binası içinde ya da Eminönü Halkevinde verilmiştir. 
